\title{
GENIUSZ CZY BIZNESMEN? SPRZĘŻENIE KARIER DROGĄ DO SUKCESU W NAUCE ${ }^{1}$
}

\author{
Izabela Wagner \\ Uniwersytet Warszawski, \\ École des Hautes Études en Sciences Sociales (EHESS)
}

„A sufficient sense of distributive and commutative justice requires one to recognize, however belatedly, that to write a scientific or scholarly paper is not necessarily sufficient grounds for designating oneself as its sole author".

(Merton 1988: 607)

„Scientific findings, scientific facts are usually thought of as symbols of certainity. But people must realize that these findings are certain only with respect to a particular frame of reference".

(Snow w: Shapin 2008: 30)

\section{/// Wprowadzenie}

Pierwsze pytanie sformułowane przez autorów prezentacji nowego pisma akademickiego „Stan Rzeczy” brzmi: jakie sa warunki sukcesu w nauce? Aby odpowiedzieć na tę kwestię, nie ograniczając się do wyliczenia specyficznych czynników dynamizujących czy też zwiększających efektywność

\footnotetext{
${ }^{1}$ Zgodnie z tradycją socjologiczna podtrzymywaną przez badaczy terenowych, a także dzięki moim własnym pracom nad karierami naukowców i głębokiemu przeświadczeniu o istotnym wpływie biografii autorów na ich dorobek naukowy, podaję podstawowe informacje dotyczące mojego warsztatu socjologicznego (szeroko pojętego jako sumę nie tylko wybranych technik badawczych, ale również istotnych elementów kontekstu kształcenia zawodowego i pewnej orientacji teoretycznej). Dokonuję tego, aby czytelnik niniejszego artykułu uzyskał wszelkie należne informacje umożliwiające mu krytyczne podejście do treści w nim zawartych. Wykształcenie socjologiczne otrzymałam we Francji w École des Hautes Études en Sciences Sociales w Paryżu, w ramach szkoły doktoranckiej specjalizującej się w socjologii edukacji i pracy. Moim mentorem był Jean-Michel Chapoulie, który jest ekspertem francuskiej socjologii edukacji, a także historykiem socjologii i znawcą tradycji chicagowskiej. Chapoulie, profesor ENS, a następnie Sorbony, od września 1968 r. przez dziesięć lat był badaczem w Centrum Socjologii Europejskiej w EHESS, kierowanym przez Pierre'a Bourdieu. Następnie utworzył własny zespół Groupe de recherche sur l'Education, le Travail et Institutions - GETI (początkowo w ENS, a następnie międzyuczelniany, obejmujący ENS, EHESS i Uniwersytet Paris 8), który działał w opozycji do dominujących w latach 80. i 90. nurtów socjologii francuskiej (nazywanych
} 
prac w nauce, należy ją przeformułować. Bardziej adekwatne wydaje się następujące pytanie: w jaki sposób odnosi się sukces w nauce? Zamiast listy zmiennych wpływających na sukces otrzymamy wtedy szerszą perspektywę, która umożliwi procesualne ujęcie tematu, a następnie odpowiedź na pytanie: czym jest sukces w nauce? Czy jest on dla każdego tym samym? Wielu specjalistów od tej kwestii jest zgodnych, że „sukces w nauce” jest istotnym elementem kariery każdego badacza (Reif, Strauss 1965; Zuckerman 1977; Merton 1988; Latour, Woolgare 1986; Hermanowicz 1999; Fridman 2001; Lamont 2009), dlatego analiza tego kluczowego zagadnienia musi być zrealizowana w szerszym kontekście karier naukowych i w odniesieniu do pracy naukowej.

Z perspektywy historii nauki XIX i XX w. nie ulega wątpliwości, że postrzeganie ludzi nauki jest dynamiczne i oscyluje między dwiema skrajnymi postaciami: wcielonego diabła i geniusza (Shapin 2008). Aktualnie w Europie potocznie postrzega się pracę naukowca jako wynik jego kompetencji i wyjątkowego ,geniuszu”. Kompetencje nabywa on w trakcie długotrwałej i intensywnej edukacji (około 25 lat kształcenia), a „geniusz”, czy też wyjątkowe zdolności lub talent, w którego istnienie wielu nie wątpi, nie stanowi cechy nabytej. Dopatrując się wyjątkowego daru natury, niebios czy jakiejś nadprzyrodzonej siły w działalności wybitnych przedstawicieli nauki, bierzemy pod uwagę istnienie niewytłumaczalnego czynnika umykającego „szkiełku i oku” socjologa. O ile wielu czytelników zgodzi się z pozycją krytyczna, zakładająca, iż jednym z zadań socjologa jest dekonstrukcja mitów i wierzeń społeczności, które badamy ${ }^{2}$, o tyle trudniej będzie nie przyznać racji stwierdzeniu, iż my sami, jako pewna społeczność, jesteśmy wolni od takich przekonań. Steven Shapin, historyk i socjolog nauki, analizując grupy zawodowe naukowców, stwierdza, że są oni podobni do innych grup zawodowych: ulegaja powszechnie panującym stereotypom

przez niektórych „terroryzmem socjologicznym Bourdieu”; Verdès-Leroux 1998), wprowadzając na jej teren tradycję badań jakościowych wzorowanych na spuściźnie chicagowskiej. Zespół ten cechowała nie tylko koncentracja na badaniach jakościowych (zwłaszcza obserwacji), lecz także - prawdopodobnie w pewnym sensie ze względu na jego działalność „opozycyjną” do wszechobowiązujących tendencji Bourdieusowskich - wysoki krytycyzm wobec dorobku naukowego, nawet tego, który był uważany za najbardziej prestiżowy (a może właśnie przede wszystkim tego). Tak więc, o ile mogłabym powiedzieć, że wywodzę się z Bourdieusowskiej tradycji poprzez Chapouliego, który działał w ekipie Bourdieu, o tyle dziesięcioletnie niemalże badania pod kierunkiem Chapouliego w ramach jego własnego zespołu dostarczyły mi narzędzi (postawa badawcza) umożliwiających odmienne spojrzenie nie tylko na francuskiego ,socjologa nr 1", ale przede wszystkim na to, co jest obiektem moich prac badawczych od dziesięciu lat, czyli działalność i kariery ludzi nauki. O tym właśnie traktuje ten artykuł. ${ }^{2}$ Everett Hughes poświęcał wiele uwagi profesjonalnym mitom, podkreślając, że środowiska cieszące się dużym prestiżem są szczególnie podatne na występowanie tego typu fenomenów (Hughes 1958: 49). 
i wierzeniom, dzieląc z szerokimi rzeszami społeczeństwa cechy uważane zarówno za pozytywne, jak i negatywne ${ }^{3}$ (Shapin 2008). Jakże wielu z nas podziela tę specyficzną wiarę w geniusz, powtarzając za innymi, iż Weber, Durkheim czy Goffman „był naprawdę genialny”! Jakże często, oceniając efekty ich pracy, zapominamy o drodze, którą musieli pokonać. Nie staramy się dotrzeć do informacji, które spowodowałyby poznanie mechanizmów środowiskowych, co sprawia, iż powszechny wizerunek naukowca to portret wybitnej osoby obdarzonej nadprzyrodzonym darem.

Niniejszy artykuł przedstawia portret odmienny od powszechnie przyjętych przez nasze środowisko konwencji (Becker 1982: $30^{4}$ ). Portet ten powstał dzięki naświetleniu tych aspektów kariery wybranego Wybitnego Naukowca ${ }^{5}$, które pozostają w cieniu, a które zarazem stanowią najistotniejsze elementy sukcesu w nauce.

Mówiąc o powszechnie przyjętym wizerunku naukowca, w celu uściślenia wywodu należy zaznaczyć, że istnieje znaczna różnica wynikająca nie tylko $z$ reprezentowanych dyscyplin, lecz także z charakteru wykonywanych czynności w ramach danej specjalności. Jest to wynik specyfiki pracy naukowej, którą w danym obszarze się wykonuje. Już w ogólnym podziale na dyscypliny humanistyczne i przyrodnicze występują znaczne różnice. Upraszczając, można powiedzieć, że w tych pierwszych dominuje organizacja pracy oparta na jednostkach: uczony samotnie pracuje nad wybranymi zagadnieniami. W naukach przyrodniczych mamy do czynienia z praca grupowa. Ten powierzchowny podział wymaga jednak uściśleń, ponieważ zarówno w naukach przyrodniczych można spotkać przykłady pracy opartej na samotnych działaniach (teoretycy), jak i można też przytoczyć wiele przykładów humanistów pracujących w licznych zespołach badawczych. Tak więc nie istnieja jedynie dwie wspomniane kategorie: należy wyróżnić wiele typów organizacji pracy naukowej (niezależnie od uprawianej dyscypliny), które funkcjonują w przestrzeni ograniczonej dwoma przeciwstawnymi modelami pracy w nauce. $\mathrm{Na}$ jednym krańcu znajduje się 300-osobowy zespół podpisujący pracę akronimem, jak np. przy projektach w dziedzinie astronomii czy nanofizyki (Pontille 2004: 183,

\footnotetext{
${ }^{3}$,We are all suffering under our own system of prejudices, and scientists are not exception to this rule, even though they may have purged themselves from some of the prejudices in their particular field" (Popper w: Shapin 2008: 23).

${ }^{4}$,The concept of convention provides a point of contact between humanists and sociologists, being interchangeable with such familiar sociological ideas as norm, rule, shares understanding, custom, or folkway, all referring to the ideas and understanding people hold in common and through which they effect cooperative activity" (Becker 1982: 30).

${ }^{5}$ Wybitny Naukowiec w tym ujęciu oznacza osobę, która zrobiła karierę międzynarodowa - termin wybitny w moim użyciu nie odnosi się do wartości prac danej osoby.
} 
zob. także np. prace realizowane w CERN) ${ }^{6}$, a na drugim widnieje jedna osoba: samotny uczony. W świecie społecznym ludzi nauki istnieje więc mnogość różnorodnych sposobów pracy, bogactwo odmiennych ścieżek realizacji karier w ramach tego środowiska, a także wiele sposobów na sukces.

Ten pluralizm nie wynika jedynie $z$ bogactwa dyscyplin i specyfiki wykonywanych prac, ale jest także w dużej mierze konsekwencją intensywnych zmian, które zachodzą w świecie nauki: umiędzynarodowienie na niespotykaną dotąd skalę wpływa na drogi zawodowe naukowców i wprowadza znaczne modyfikacje ich sposobu pracy. W ślad za specjalistami nauk eksperymentalnych, którzy coraz już rzadziej realizują projekty, pracując w ekipach i korzystając ze środków pochodzących tylko z jednego kraju, podążają specjaliści nauk społecznych, łacząc swe wysiłki, aby odpowiedzieć wymaganiom, które są im stawiane przez polityków nauki, finansistów i ich własne środowisko. Coraz częściej specjaliści nauk, w których podstawa pracy był dotychczas tandem mistrz - uczeń lub mały zespół, decyduja się na udział w masowych projektach badawczych i szerokich przedsięwzięciach, co znacznie modyfikuje ich działalność.

Niemniej jednak, mimo tych istotnych zmian i przesunięć w organizacji pracy naukowej w kierunku badań zespołowych, jej rezultaty, uzyskane przecież dzięki wysiłkom wielu osób, są sygnowane nazwiskami poszczególnych osób, a nie nazwa grupy badawczej czy zespołu! (Nazwa instytucji, która reprezentują dane osoby, stanowi dodatkowa - drugorzędną na ogół - informację.) Dzieje się tak, ponieważ po dziś dzień osiagnięcia naukowe przypisywane są jednostkom, a nie zespołom. Tutaj właśnie sięgamy istoty naszych rozważań: każdy z nas - ludzi nauki - kumuluje owoce swej pracy pod własnym nazwiskiem (prestiz $=$ kapitał symboliczny $=$ nasz kapitał zawodowy ${ }^{7}$ ). W ten sposób sukces ma jednego rodzica! Tak postrzegamy i oceniamy działalność naszych kolegów i naszą własną. W środowisku specjalistów nauk humanistycznych najczęściej przypisujemy daną pracę zbiorową jednej osobie: rzadko pamiętamy o tandemach, nie wspominając już o autorach prac zbiorowych - nie sposób wszak zapamiętać nazwisk ich wszystkich ${ }^{8}$ ! W tym ostatnim przypadku najczęściej autor, który jest

\footnotetext{
${ }^{6}$ Analiza procesu sygnowania prac naukowych jest tematem książki Davida Pontille’a (2004) La signature scientifique. Une sociologie pragmatique de l'attribution.

${ }^{7}$ Używam tutaj tych terminów zgodnie z potocznym, czyli wewnątrzśrodowiskowym znaczeniem - wprowadzone przez Bourdieu koncepcje weszły do potocznego języka pracowników nauki, stając się popularnymi określeniami używanymi w rozmowach o własnych karierach.

${ }^{8}$ Tego typu przeświadczenia mogą kształtować się pod wpływem lokalnej kultury. Jak zaznaczała prof. Elżbieta Hałas w trakcie swych zajęć, można zaobserwować istotną różnicę między liczbą podziękowań występujących w publikacjach północnoamerykańskich i polskich. Podobną różnicę można zauważyć między publikacjami francuskimi a amerykańskimi. Może to sugerować, że w Europie eksponuje
} 
najbardziej znany, przejmje niejako autorstwo całego dzieła. Doskonałym przykładem opisującym to zjawisko jest sposób zapamiętywania autorów znanego dzieła Chłop polski w Europie i Ameryce. Jakże nas, Polaków, oburza fakt, że poza nami nikt nie potrafi przytoczyć polskiego współautora książki - Floriana Znanieckiego! Natomiast w Polsce często mamy kłopot z podaniem właśnie nazwiska amerykańskiego socjologa - Willliama Thomasa! Robert Merton, a raczej Merton i Zuckerman, przedstawili ten mechanizm w nawiązaniu do efektu św. Mateusza (Merton 1968, 1978, 1988; Pontille 2004; Wagner 2009). Fenomen ten polega m.in. na przypisaniu autorstwa osobie o znanym nazwisku w przypadku publikacji zbiorowej, przy równoczesnym zepchnięciu niejako w cień nieznanych współautorów, mimo ich wkładu pracy w dane dzieło. Jest to typowy efekt oddziaływania reputacji w pewnych środowiskach. W niniejszym artykule poruszę kwestię tego fenomenu nie tylko w odniesieniu do nierzadkich przypadków przeniesienia ciężaru autorstwa na jednego $\mathrm{z}$ autorów wbrew oczekiwaniu i woli nawet tych, którzy korzystaja z tego efektu. Zajmę się także problemem celowego wykorzystywania fenomenu św. Mateusza. Wskażę, w jaki sposób funkcjonuje mechanizm kumulacji prac zbiorowych pod jednym „nazwiskiem”.

Można przypuszczać, że w naukach humanistycznych istnieje większe ryzyko występowania tego typu zjawisk. Jest to między innymi spowodowane faktem, że humaniści - ogólnie mówiąc - nie opanowali jeszcze praktyk, które cechują ich kolegów reprezentujących nauki przyrodnicze, a zwłaszcza środowiska prowadzące badania eksperymentalne. Jako badacz tych środowisk wiele razy mogłam obserwować biologów, biochemików, fizyków i innych specjalistów, którzy, czytając pracę autorstwa kilkunastu osób, analizuja ją, starając się odgadnąć autora tej czy innej części badania. W ten sposób odkrywaja „mózgi” zespołu. Starają się zrekonstruować role, jakie każdy z autorów odegrał w ramach opublikowanej pracy. W porównaniu do tych środowisk - na podstawie moich wieloletnich obserwacji - mogę stwierdzić, że nie tylko niektórzy przedstawiciele nauk humanistycznych sprawiaja wrażenie, jakby nadal żywili przeświadczenie, iż dorobek naukowy jest rezultatem bycia „Wyjątkowym Uczonym”, ale przede wszystkim niewiele $\mathrm{w}$ naszym środowisku mówiono czy pisano na temat organizacji pracy naukowej w kontekście działań zbiorowych czy też samej specyfiki karier naukowych ${ }^{9}$. Niniejszy artykuł ma na celu

się wkład autora, nie przykładając wagi do osób, które pomagały czy też inspirowały go do napisania tekstu lub przeanalizowania danych.

${ }^{9} \mathrm{~W}$ ostatnich latach można zauważyć ożywienie w tej tematyce, głównie w USA: np. specjalny numer „American Sociologist” 2005, vol. 36, nr 2, czy publikacja M. Lamont (2009). 
uzupełnienie tego istotnego braku - z pewnością niewyczerpujące, niemniej jednak potrzebne.

$\mathrm{Na}$ podstawie analizy wybranego przypadku - socjologa uważanego za człowieka, który niewątpliwie odniósł sukces - przeanalizuję proces konstruowania kariery w świecie nauki. Artykuł składa się z trzech części. Po krótkim wstępie poświęconym kluczowym dla niniejszej publikacji koncepcjom dokonam analizy kariery wybitnego socjologa. Przedstawię jego socjologiczny portret, zwracając uwagę na te elementy, które zostały zepchnięte w cień - zarówno przez samego bohatera, jak i społeczność naukową. Skupię się w tej części na jego wybranych współpracownikach i roli, jaką odegrali w budowaniu ,wielkiej kariery”. Wskażę, w jaki sposób przyczynili się oni do indywidualnego sukcesu naszej głównej postaci.

Ze względu na złożoność zjawiska, które potocznie nazywamy sukcesem, druga część tej pracy zostanie poświęcona przedstawieniu wielu różnorodnych aspektów, które spowodowały, że wybrana publikacja naszego bohatera odniosła sukces wydawniczy na niespotykaną skalę i stanowiła punkt zwrotny w jego karierze. W tej części nie tylko przedstawię rolę współautora $\mathrm{i}$ współpracowników w powstaniu tego dzieła, ale wskażę na inne czynniki, które spowodowały, że wybrany socjolog stał się sławny w swym kraju. Na podstawie wyżej przytoczonych danych i dokonanej analizy w konkluzji dokonam sformułowania definicji sukcesu w nauce w dynamicznym kontekście organizacji pracy typowej dla XXI w. Podsumuje także funkcjonowanie uprzednio przedstawionych mechanizmów, wskazując na inne przykłady działania opisanych zjawisk.

W ten oto sposób moje socjologiczne zadanie, którego się tutaj podjęłam - czyli dekonstrukcja wewnątrzśrodowiskowego mitu - zostanie uwieńczone (mam nadzieję)... sukcesem!

\section{/// Narzędzia metodologiczne i teoretyczne}

Nie będę tutaj dyskutować na temat procesu powstawania idei w odniesieniu do autorów, ponieważ podobnie jak Robert Merton (patrz motto wprowadzające) uważam, że niezmi nie trudno jest wyznaczyć rodzicielstwo pomysłów i koncepcji, które zawsze tworzą się w wyniku interakcji z innymi osobami (żywymi - przez rozmowy - czy też za pośrednictwem lektur). W niniejszej publikacji posłużę się narzędziami używanymi w socjologii karier i dokonam analizy kariery naukowej wybranego autora, który jest niewątpliwie uważany za jednego z najważniejszych socjologów XX w. 
Moim przykładem w swoistym case study na potrzebę dalszych rozważań będzie kariera Pierre’a Bourdieu. W celu wyłonienia jak największej liczby elementów wpływających na realizację kariery w nauce wybrałam właśnie ten, niewattpliwie skrajny przypadek. Wybór taki jest w pełni podyktowany przesłankami metodologicznymi. Jak podkreśla w swoich pracach dotyczących karier literatów francuska socjolożka Natalie Heinich, przydatność analiz dotyczących tzw. skrajnych przypadków (cas limite) jest wyjątkowo duża (Heinich 1999, 2000). Dzięki swojej ekstremalności uwypuklaja - czy też uwidaczniaja - bowiem one te cechy, które pozostałyby w cieniu analizy, gdyby nie ich wyrazistość.

Nie ulega wątpliwości, że kariera Bourdieu jest skrajnym przypadkiem kariery socjologa. Przedstawia się ja jako pasmo sukcesów, a on sam jest niewattpliwie postrzegany jako jeden z najważniejszych socjologów drugiej połowy XX w. O ile kilkadziesiąt lat temu w odniesieniu do jego kariery można było bez wahania mówić o sukcesie francuskim, następnie, w późnych latach 70., wskazywać na sukces europejski, o tyle aktualnie, na podstawie wielkiego zainteresowania tym autorem w Stanach Zjednoczonych, można powiedzieć zdecydowanie, iż odniósł on sukces na skalę światową ${ }^{10}$. Tak więc wybór kariery Bourdieu jako extreme case jest w pełni uzasadniony.

Posługując się terminem kariera, bazuję na definicji powstałej na gruncie interakcjonizmu symbolicznego i wykorzystywanej powszechnie w socjologii pracy. Everett Harrington Hughes (1996), Howard Saoul Becker (1970) oraz Becker i Anselm Strauss (1956) uważaja, że kariera jest droga zawodową danej osoby, składająca się z łańcucha etapów następujących po sobie i różniących się między sobą jakością interakcji, w które są zaangażowane osoby należące do otoczenia zawodowego i odgrywające $\mathrm{w}$ danym środowisku istotną rolę.

W celu wyłonienia tych aspektów, które nie są brane pod uwagę $\mathrm{w}$ analizach drogi zawodowej osób będących autorytetami w swym środowisku, w niniejszym artykule posłużę się koncepcją sprzężenia karier. Została ona opracowana na podstawie badań nad artystami - wirtuozami skrzypiec, a następnie poddana weryfikacji w środowisku specjalistów nauk przyrodniczych (Wagner 2005). Sprzężenie karier jest procesem społecznym, powszechnie występującym w grupach profesjonalistów. Polega on na wzajemnym oddziaływaniu na siebie dwóch lub więcej karier. Proces

\footnotetext{
${ }^{10}$ Po nominacji profesorskiej w College de France (1981), a także licznych problemach i zerwaniach współpracy z przedstawicielami francuskiej elity socjologicznej (J.C. Passeron, L. Boltanski, C. Grignon, J. Verdes-Leroux i in.), Bourdieu podbija „rynek intelektualny międzynarodowy, głównie USA (Princeton, PENN-U)" (Dortier 2002: 9).
} 
ten przebiega w ciagu wielu lat i jest realizowany w trzech etapach: 1 . selekcja i okres próbny, 2. aktywna współpraca nazwana fuzją i 3. pasywna współpraca. Pierwszy etap sprzężenia, trwający na ogół kilka miesięcy, polega na wzajemnej selekcji, a następnie okresie próbnym, w którego trakcie partnerzy sprzężenia dopasowują wzajemnie oczekiwania i uczą się efektywnej komunikacji, która umożliwi im poziom porozumienia charakterystyczny dla następnego etapu. W drugim okresie sprzężenia - aktywnej współpracy - następuje tak intensywna dynamika pracy, że najczęściej dochodzi do zaniku podziału między życiem zawodowym a osobistym. $\mathrm{Na}$ tym etapie (czasami trwa on kilka, a w wyjątkowych wypadkach kilkanaście lat) dochodzi do swoistej „fuzji” między partnerami sprzężenia karier. Dzięki intensywności działań i specyficznej dynamice pracy jej efekty są postrzegane przez otoczenie jako wyjątkowej wartości, a reputacje tych osób staja się wskutek tego fenomenu powiązane. Obaj uczestnicy tego procesu pokonują kolejne etapy swej kariery dzięki wynikom ich ścisłej współpracy. Ostatni etap sprzężenia karier - współpraca pasywna - polega głównie na podtrzymaniu relacji z partnerem - dotychczasowym bliskim współpracownikiem - przy jednoczesnym zaniku aktywnej i intensywnej współpracy. Niemniej jednak byli uczestnicy sprzężenia podtrzymuja w swym środowisku wiedzę o relacji ich wiążącej, w celu utrzymania wzajemnej reputacji ${ }^{11}$ (przypominają o ,kapitale społecznym” - używając terminu spopularyzowanego ${ }^{12}$ przez Bourdieu - zbudowanym na wzajemnej relacji). Śledząc trajektorię zawodową danej osoby, można wyodrębnić jeden lub kilka przykładów takiego zjawiska. Jednakże, ze względu na czas, jaki jest konieczny do utrzymania tego typu intensywnej relacji, najczęściej osoby angażują się w aktywną współpracę, charakterystyczną dla powyższego procesu, tylko z jedną osobą. Powszechnie mówi się o takich współpracownikach jako o bliskich partnerach zawodowych, o tandemie czy też „binomie”.

Dzięki sprzężeniu karier uczestnicy kontrolują nie tylko wejście do ich środowiska, ale także dynamikę pozycji zajmowanych przez członków danej grupy. John Ziman stwierdza, że „pozycja w środowiskach [naukowych] zależy od reputacji, która jest nienamacalna i często efemeryczna" (Ziman 1987: 84). Dynamika karier w środowiskach intelektualistów i artystów przypomina mechanizm sprzężenia zwrotnego, dzięki któremu członkowie danej grupy przemieszczaja się w swej przestrzeni zawodowej. Proces ten jest widoczny we wszystkich środowiskach elitarnych. Należy jednak

\footnotetext{
${ }^{11}$ Tego typu praktyki nie są stosowane w przypadkach, w których reputacja jednej z osób zostanie osłabiona (Wagner 2006).

${ }^{12}$ Termin „kapitał społeczny” po raz pierwszy został użyty przez Lydę Judson Hanifana w 1916 r. (Putnam 2000: 19).
} 
zaznaczyć, że powyższa definicja dotyczy „modelowego” przypadku. Badania wykazały bogactwo odmian opisanego procesu, niemniej jednak analiza karier osób działających w badanych środowiskach przy użyciu koncepcji sprzężenia karier umożliwia wyłonienie tych aspektów, które często pozostawały w cieniu analiz dokonywanych za pomoca podejścia do fenomenu kariery jako do procesu linearnego dotyczącego jednostki.

Ponieważ wychodzę z założenia, że w środowiskach, w których kariery konstruuje się nie samodzielnie, ale na bazie wysokiego poziomu specjalistycznej ekspertyzy i reputacji środowiskowej, a proces sprzężenia karier umożliwia osobom konstrukcję ich drogi zawodowej, przedstawię trajektorię ${ }^{13}$ zawodową Bourdieu, odwołując się do tej koncepcji. W ten sposób postaram się zwrócić uwage czytelników na kolejnych bliskich współpracowników francuskiego autora. Ponieważ nawet w obszernym artykule nie sposób uwzględnić wszystkich osób, które tworzyły swoisty tandem z najbardziej popularnym socjologiem francuskim drugiej połowy XX w., skoncentruję się jedynie na wybranych postaciach (Abdelmalek Sayad, Monique de Saint-Martin, Jean-Claude Passeron) i wybranych dziełach, które będą przykładem analizowanych procesów. Wspomnę także o innych współpracownikach francuskiego socjologa. Natomiast nie będę rozważała kwestii teoretycznych związanych z Bourdieu, ponieważ powstało wiele krytycznych publikacji w tym zakresie, głównie w obszarze socjologii francuskojęzycznej (Grignon, Passeron 1989; Grunberg, Scheisguth 1996; Verdès-Leroux 1998; de Singly 1998; Lacoste-Dujardin 1997, 1998-1999, 2007; Verdrager 2010). Kariera naukowa Bourdieu jest tutaj wykorzystana jedynie jako niesłychanie inspirujący przykład analiz typowych dla socjologii karier i organizacji.

\section{/// Algieria: wojna, antropologia i Abdelmalek Sayad}

\section{Kontekst wolny wyzwoleńczej, odkrycie antropologii i bada- nia terenowe}

Pierwszym terenem badawczym Pierre’a Bourdieu była Algieria. To właśnie w tej „części Francji”, na skutek zderzenia z „codziennością społeczeństwa algierskiego, zdezintegrowanego przez kolonizację i wojnę”, a także na skutek jego osobistych doświadczeń ${ }^{14}$, dokonało się przeistoczenie

\footnotetext{
${ }^{13}$ Biorąc pod uwagę karierę Bourdieu, jest ona przykładem nieomal idealnej trajektorii francuskiego pracownika nauki. Począwszy od elitarnej ENS, przez Sorbonę, EPHS (przemianowanej potem na EHESS) aż po Collège de France - jest to „modelowa” ścieżka kariery.

${ }^{14}$ Sam Bourdieu podkreślał, jak ważne w jego życiu naukowym były doświadczenia z dzieciństwa i młodości. Syn listonosza wywodzącego się z niezamożnej rodziny chłopskiej, opisuje swe doświadczenia jako drogę niemalże wiecznego „outsidera” - począwszy od pierwszych lat szkolnych
} 
intelektualne Bourdieu ze świeżo dyplomowanego filozofa na socjologa (Yacine 2003: 335). Zdając się na słowa samego Bourdieu, napisane pod koniec życia, to w Algierii, dzięki doświadczeniu etnologicznemu ${ }^{15}$, zdał on sobie sprawę ze złożoności procesów społecznych i konieczności prac terenowych. Nabrał wtedy przekonania o adekwatności pozycji etnologów, która zarazem uwypuklała nieprzydatność filozofii czy też ukazywała ograniczoność wykorzystania socjologii do analizy sytuacji i zagadnień, które zdecydował się on badać. Bourdieu określa swe doświadczenie algierskie terminem inicjacji (Bourdieu 2004: 78). Początkowo odejście od filozofii miało być tymczasowe, na okres prac nad pierwszą książką Sociologie de l'Algérie (1958), ale następnie okazało się definitywne - autor podkreśla tutaj istotny wpływ prac Levi-Straussa (Bourdieu 2004: 53-57).

W Algierii, miejscu tego przełomu, 25-letni Bourdieu znalazł się jesienią 1955 r., jako rekrut wysłany do kolonii, w której od 1954 r. trwały rozruchy wojenne (warto podkreślić, że nie używano wtedy określenia wojna - Algieria wszak była nie kolonią, ale częścią Francji). Absolwent elitarnej École Normale Supérieure, świeżo mianowany nauczyciel filozofii w liceum w mieście Moulin, początkowo miał odbywać służbę jako podoficer we Francji kontynentalnej. Z powodów ideologicznych (sprzeciw wobec obowiązku zachowywania hierarchii i odmowa bycia podoficerem) po kilku miesiącach (przygotowanie szeregowców w Chartres, a następnie krótki pobyt w elitarnej jednostce byłych studentów ENS w Wersalu) został wcielony za karę ${ }^{16}$ do oddziałów interwencyjnych w Algierii. Na początku swego pobytu w Afryce Bourdieu służy w jednostce poza Algierem (wykonując prace administracyjne), ale dzięki rodzinnym koligacjom udaje mu się uzyskać oddelegowanie do pracy w Biurze Dokumentacji i Informacji (kierowanym przez prawnika M. Faugère) przy Rządzie Generalnym w stolicy Algierii. Miejscem jego pracy jest jedna z bibliotek Algieru. Ponieważ jest ona najlepiej wyposażona, Bourdieu spotyka tam wszystkich badaczy, którzy znają doskonale ten kraj i pomoga mu nie tylko w znalezieniu cennych informacji, ale także w ich interpretacji. Intelektualna atmosfera tych lat

\footnotetext{
w miasteczku regionu Bearn, później w liceum w Pau, a następnie w elitarnej École Normale Supérieure i wśród akademickiego establishmentu.

${ }^{15}$ Mowa jest tutaj o badaniach terenowych, które we francuskiej socjologii były przypisywane etnologom. Bourdieu nie znał wtedy wystarczająco literatury chicagowskiej (brak tłumaczeń na francuski, a także brak zainteresowania francuskich czytelników tą literaturą; Chapoulie 2001), nie mógł więc wiedzieć, że badania jakościowe stanowiły także domenę socjologów. Etnologia francuska (przez Levi-Straussa) miała niejako „monopol” na prowadzenie badań terenowych.

${ }^{16}$ Głównym powodem decyzji ukarania Bourdieu było prenumerowanie przez niego tygodnika „Express” (w owych czasach uznawanego za postępowy i przeciwnego interwencji w Algierii) i wyrażanie „niepożądanych” opinii na temat Algierii francuskiej (Bourdieu 2004: 54-55).
} 
w Algierze jest obciążona klimatem „terroru wobec przeciwników Algierii francuskiej" (Castel 2005: 336), a więc niesprzyjającym rozwojowi i uprawianiu nauk społecznych. Mimo to w 1958 r. ukazuje się pierwsza książka francuskiego socjologa, napisana na podstawie prac zrealizowanych właśnie w tym okresie, zatytułowana Sociologie de l'Algérie i wydana przez Press Uniwersitaires de France w kolekcji „Que sais-Je? Le point de connaissance actuelle". Zdecydowana większość danych wykorzystanych w książce jest wynikiem pracy w archiwum, a także licznych rozmów z socjologami $\mathrm{i}$ intelektualistami działającymi w Algierze.

Bourdieu już w okresie tych pierwszych doświadczeń badawczych potrafił zbudować zespół stworzony z najlepszych specjalistów: archiwista i bibliograf Dermenghem, historyk André Nouschi i profesorzy zatrudnieni na uniwersytecie algierskim. Bezcenna w tym doświadczeniu (fundamentalnym dla życia naukowego Bourdieu) jest współpraca z intelektualistami algierskimi (i proalgierskimi), którzy nie tylko wprowadzaja go w specyfikę miejscowej „kultury”, ale równocześnie umożliwiaja poznanie ,z drugiej strony” konfliktu francusko-algierskiego. Znaleźli się wśród nich Mouloud Feraoun, Mouloud Mammeri i wielu studentów, których włącza do swych prac: Henine (zginął w trakcie prac badawczych), Accardo, Leila Balhacène, Rolande Garèse, Mimi Bensmaine, Ahmed Misraoui, Mahfoud Nechem (Bourdieu 2004: 77). Ale kluczowa postacią w tym okresie pracy Bourdieu jest Abdelmalek Sayad, który zwerbował większość algierskich współpracowników Bourdieu - były to osoby „pewne” ${ }^{17}$, zaangażowane w ruch wyzwoleńczy i mające kompetencje lub potencjał badacza. To właśnie Sayad stanie się uprzywilejowanym współpracownikiem Bourdieu - ich wieloletnia relacja stanowi nieomalże klasyczny przykład sprzężenia karier.

\section{Abdelmalek Sayad - etudiant „pas comme les autres” (Sayad - student nie taki jak inni)}

W latach 1959-1960 w Algierii trwała wojna wyzwoleńcza i klimat w stolicy nie sprzyjał realizacji badań terenowych. Mimo to Bourdieu, równolegle z pracą na uniwersytecie w Algierze ${ }^{18}$, podjął się prac badawczych. Polegały

\footnotetext{
${ }^{17} \mathrm{~W}$ tym okresie wywiad francuski intensywnie inwigilował grupy algierskich i francuskich intelektualistów, którzy opowiadali się za wyzwoleniem Algierii. „Osobami pewnymi” byli ludzie o lewicowych poglądach - niezwiązani z prawicowymi siłami działającymi w tym kraju (Sorbona była wtedy ośrodkiem popierającym konserwatywną politykę utrzymania za wszelką cenę Algierii francuskiej).

18 Bourdieu mógł wykładać na uniwersytecie, ponieważ według ówczesnych przepisów francuskich osoby posiadające agregację - dyplom pedagogiczny - mogły bez doktoratu prowadzić zajęcia na
} 
one na zbieraniu informacji na temat warunków mieszkaniowych populacji Kabilii - osób mieszkających poza stolica. W kraju ogarniętym wojna zdecydowano się na badania centrów zgrupowania migrantów (ze wsi), a także gromadzenie danych na temat warunków życia mieszkańców wsi. Badaczy interesowal masowy odpływ ze wsi do miast, zanikanie kultury wiejskiej w kontekście kolonialnym i walk wyzwoleńczych (oczywiście oficjalnie mówiło się jedynie o przepływie ludności ze wsi do miast). Administrator algierskiej sekcji INSEE (odpowiednik GUS-u) Alain Darbel (specjalista-statystyk, którego nazwisko przewija się przez następne kilkadziesiąt lat u boku Bourdieu jako jednego z najważniejszych jego współpracowników) ze względów politycznych nie był chętny do współpracy z socjologami i opracował taką próbę badawcza, która ominęła miejscowości położone na obszarach objętych walkami (Darbel tylko początkowo był przeciwnikiem wyzwolenia Algierii). Bourdieu sprzeciwił się takiemu wyborowi i mimo grożącego niebezpieczeństwa spowodowanego powstańczymi walkami udał się w regiony opanowane częściowo przez partyzantów algierskich.

\section{Sprzężenie karier - selekcja i okres próby (dostosowanie wymagań)}

Prowadzenie zamierzonych prac badawczych w warunkach quasi wojennych byłoby niemożliwe bez pomocy autochtonów, a szczególnie Abdelmaleka Sayada. Sayad nie był „zwykłym studentem”, który asystował w pracach swego wykładowcy. O trzy lata młodszy od Bourdieu, był „outsiderem” wśród innych studentów, którzy przychodzili na wykłady z filozofii prowadzone przez francuskiego wykładowcę. Pochodził, podobnie jak Bourdieu, z małej miejscowości. Urodził się w rodzinie niezamożnej, w której jednak wykształcenie było najwyższą wartością: jego dziad poświęcił wszystkie swe oszczędności na budowę wiejskiej szkoły. Nie jest więc przypadkiem, że Abdelmalek po pokonaniu wszystkich szczebli edukacji (francuskie ideały szkoły „republikańskiej” funkcjonowały w pewnym stopniu także w Algierii, co umożliwiało najlepszym uczniom kształcenie się nie tylko w wiejskich szkołach, ale nawet na uniwersytecie). Sayad

uniwersytecie (we Francji do 1983 r. wyróżniano doktorat i tzw. These d’État - czyli „duży” doktorat. Agregacja była dyplomem pomiędzy obiema formami doktoratu. Dopiero F. Mitterand zniósł podział i ujednolicony doktorat stał się ważniejszy niż agregacja). Bourdieu nigdy zresztą nie dokończył prac nad swym doktoratem i nie obronił go. Przepisy EHESS - w którym wiele lat pracował - a następnie regulamin College de France, jako instytucji wyjątkowo elitarnych i autonomicznych, nie wymagały od wykładowców posiadania tego dyplomu, uważanego za dyplom naukowy, a nie dydaktyczny. Natomiast uniwersytety bardziej zależne od Ministerstwa nie mogą zatrudniać na stanowisku adiunkta osób bez tytułu doktora. 
skończył algierską École Normale i zaczął pracować jako nauczyciel. W momencie spotkania z Bourdieu Abdelmalek miał solidne doświadczenie nauczyciela w Barberousse casbah Algieru, czyli w dzielnicy biedoty. Równolegle był jednym z aktywnych działaczy algierskiego ruchu oporu. W tym czasie, gdy Sayad zwerbował do pomocy w zbieraniu danych znane sobie osoby zaangażowane w ruch wyzwoleńczy, a jednocześnie studiujące na Uniwersytecie w Algierze, rozpoczął się okres intensywnej współpracy wyjazdów w teren i prowadzenia badań etnograficznych ${ }^{19}$.

\section{Okres aktywnej współpracy: fuzja i teren „wojenny”}

Wspólpraca z francuskim socjologiem nie była dla Sayada „terminowaniem u mistrza”, jak przedstawiał to później sam Bourdieu, wymieniając Abdelmaleka jako jednego $\mathrm{z}$ algierskich studentów, którzy pomagali mu w badaniach (wrócę do tej kwestii w dalszej części). Od pierwszego wyjścia w teren Sayad odgrywał rolę „uprzywilejowanego uczestnika” i „oświeconego informatora” (Boltanski 2003: 154) w znaczeniu antropologicznym - autochtona, z którym badacz może się komunikować nie tylko ze względu na potrzebę tłumaczeń (z arabskiego i jego kabilskiej odmiany) czy też wyjaśnienia wierzeń i znaczeń właściwych dla badanej kultury. Jego rola polegała także na wprowadzeniu i towarzyszeniu w pracach realizowanych na terenach opanowanych przez opozycjonistów reżimu francuskiego. Było to z pewnościa przedsięwzięcie niezwykle niebezpieczne dla francuskiego socjologa. Z jednej strony, sama obecność w regionach opanowanych przez partyzantkę algierską była dla Bourdieu jako Francuza wielkim ryzykiem. Dzięki Sayadowi udało się uniknąć wielu sytuacji, groźnych dla ludzi nienależących do lokalnej społeczności kabylskiej. Z drugiej strony, współpraca $z$ francuskim socjologiem była ryzykowna także dla Sayada - mógł przecież zostać uznany przez swą społeczność za zdrajcę. Jego poświęcenie dla realizacji tego wspólnego projektu było niezwykłe (jeden uczestnik wyprawy badawczej zginął od kuli). Tak więc rola Sayada była kluczowa - jego wkład determinował realizację badań terenowych w Algierii. Relacja między partnerami sprzężenia karier w tym okresie była oparta na intensywnej długoletniej współpracy i wymianie doświadczeń. Wiele wywiadów jeżeli nie większość - przeprowadzał sam Abdelmalek. Bourdieu wspomina

\footnotetext{
${ }^{19}$ Warto tutaj podkreślić, że w swej ostatniej ksiażce Bourdieu nie tylko określa siebie mianem antropologa, ale także wyraża się w sposób niezwykle krytyczny o ankietach (w ogóle), podkreślając nieprzydatność tej metody i zarazem walory etnografii (Bourdieu 2004: 70). Wydaje się to niespójne z jego dorobkiem - pierwsza najbardziej znana książka Bourdieu i Passerona, a także następne (Reprodukcja, Distinction, La Noblesse d'État i wiele innych), powstały głównie na podstawie badań ankietowych.
} 
o ponad setce wywiadów zrealizowanych wspólnie z Sayadem, który był nie tylko tłumaczem ${ }^{20}$ (Bourdieu 1998). Bourdieu jako Francuz nie mógł sam przeprowadzać wywiadów w regionach wiejskich Kabylii z oczywistych przyczyn: politycznych, językowych, a także społeczno-kulturowych. Natomiast Sayad nie tylko znał język i był jednym ze „swoich”. Ceniono go także za niezwykłą umiejętność słuchania. Jest to kluczowa cecha u tych socjologów, dla których wywiad jest głównym narzędziem zdobywania danych. Wyjątkowa skromność i empatia, a także rzadko spotykane „otwarte horyzonty myślenia” i nieprzeciętna inteligencja, której towarzyszył rygor naukowy, sprawiały, że Sayad był niepoślednim socjologiem (Temime 1999: 268). W trakcie trwających nieraz tygodnie samochodowych podróży po różnych regionach Algierii Sayad i Bourdieu dyskutowali godzinami na temat swojej pracy. Wymieniali wspomnienia dotyczące wsi, które obaj znali z dzieciństwa: Bourdieu - wsi z okolic Bearn, a Sayad - kabylskiej (Gouirir 2007). Wspólnie analizowali zdobywany materiał, rozważając problemy dezertyfikacji regionów rolniczych i starając się zrozumieć proces zanikania świata wiejskiego w Algierii i Francji. Niewiele zostało notatek opisujących ich współpracę.

Ze względu na prace terenowe realizowane w rejonach objętych walkami, a także z powodu swych sympatii dla algierskich partyzantów Bourdieu znalazł się na czarnej liście intelektualistów niepopierających utrzymania francuskiej Algierii i jesienią 1959 r. musiał pośpiesznie opuścić Afrykę (groziło mu aresztowanie, więc członek rodziny - wojskowy namówił go do wyjazdu). Wraz z wyjazdem Bourdieu ustaje intensywna współpraca obu socjologów, zamykając zarazem drugi etap sprzężenia karier - okres aktywnej współpracy i fuzji.

\section{Współpraca pasywna: „przyjaciel i brat”}

Współpraca pasywna polega na utrzymaniu pewnego typu relacji między partnerami sprzężenia karier, dzięki pielęgnowaniu wzajemnych wpływów ich reputacji. O ile opisywany poprzedni etap współpracy mógł być uznany za zbliżony do modelu procesu sprzężenia, o tyle trzeci etap stanowi przypadek niesymetrycznego rozłożenia reputacji. Kariera Sayada rozwija się nieproporcjonalnie do kariery Bourdieu. Wkład algierskiego socjologa w badania nad Kabylia zostaje także zminimalizowany do roli tłumacza (tzw. nativa). Dalsza współpraca Sayada z Bourdieu, wiele lat później

${ }^{20}$ Do tej liczby należy dodać wywiady zrealizowane przez innych algierskich współpracowników Bourdieu. 
(badania nad wiejską społecznością w Bearn), pozostaje także w ukryciu. Bourdieu stopniowo jawi się jako kluczowy - jeżeli nie jedyny - socjolog w badaniach nad Algieria przełomu lat 50. i 60. ${ }^{21}$ Jak do tego doszło?

Po powrocie z Afryki Bourdieu zajmuje stanowisko asystenta Raymonda Arona - profesora Sorbony, a także zostaje sekretarzem w uworzonym przez Arona Centrum Socjologii Europejskiej, którym od 1968 r. będzie oficjalnie kierował. Sayad zostaje w Algierii, ale w okresie powojennym ma wielkie trudności z otrzymaniem pracy. Nie ma jeszcze publikacji z przeprowadzonych badań, a także dyplomu uniwersyteckiego. W 1963 r. dzięki pomocy pewnego algierskiego przyjaciela przyjeżdża do Paryża, gdzie otrzymuje czasowy kontrakt w Centrum kierowanym przez Arona (a później Bourdieu). Wspólna ich publikacja z 1964 r., Le Déracinement. La crise de l'agriculture traditionnelle en Algérie, zdobywa względny rozgłos, ale sytuacja polityczna nie sprzyja pozytywnemu przyjęciu tej książi ${ }^{22}$. Kolejne prace Sayada ukazuja się wiele lat później, mimo że kontynuuje on swe badania nad migracjami natychmiast po przyjeździe do Francji. Dopiero w 1977 r. Sayad otrzymuje stałą pracę w CNRS (francuski odpowiednik PAN-u) i zostaje dyrektorem grupy badawczej. Funkcję tę pełni do śmierci w 1998 r.

W klasycznym przykładzie sprzężenia karier w trzecim etapie każdy z partnerów procesu dokłada starań, aby wskazać, jaką rolę pełnił jego partner w trakcie współpracy - ma to na celu poinformowanie środowiska o podziale pracy w uprzednim etapie (fuzji). Szczególnym momentem pewnego bilansu jest śmierć jednego ze współpracowników. Wtedy ten, który pozostał przy życiu, dokonuje retrospekcyjnej analizy, podkreślając wkład partnera w ich wspólne dokonania.

Swą mowę na cześć zmarłego Sayada, wygłoszoną w Instytucie Świata Arabskiego, Bourdieu zaczyna słowami: ,Abdelmalek Sayad był dla mnie przyjacielem, więcej niż przyjacielem, był prawie bratem” (Bourdieu 1998). Może więc dziwić fakt, że ten prawie brat - a raczej jego wkład w kolejną publikację Bourdieu - nie jest nawet wspomniany. Mam tutaj na myśli książkę Le bal des célibataires. We wstępie Bourdieu wspomina innych współpracowników i dokładnie opisuje ich wkład w prace nad publikacja

\footnotetext{
${ }^{21}$ Sayad jest określany mianem ,specjalisty od emigracji”, a więc odnosi się ten termin do późniejszych badań realizowanych we Francji.

${ }^{22} \mathrm{~W}$ tym samym roku zostaje wydana praca zbiorowa Travail et travailleurs en Algérie, autorstwa Bourdieu, Darbela, Riveta, Seibela. Bourdieu był odpowiedzialny za redakcję tekstu - wszystkie inne prace zostały wykonane przez współautorów (patrz HyperBourdieu - oficjalna witryna informacyjna o publikacjach Bourdieu). Inni współpracownicy odgrywający kluczową rolę w pracach algierskich to: Chamboredon, Colonna (statystyk), Robert Castel (dołączył później). Z tymi spośród nich, którzy wykazali się dużym profesjonalizmem i entuzjazmem dla prac badawczych, Bourdieu kontynuował współpracę po powrocie do Francji.
} 
(Marie-Claire Bourdieu - żona autora, a także statystyk Claude Seibel). Natomiast najważniejsza osoba, uczestnicząca od samych początków w badaniach dotyczących społeczności wiejskich - tematyki właśnie rozpoczętej w Algierii - nie została tutaj nawet wspomniana! A przecież Sayad nie tylko realizował wspólnie z Bourdieu obserwacje w Bearn (podstawa tej publikacji), ale także wielokrotnie omawiał ze swoim przyjacielem zebrany wspólnie materiał, porównując problemy zanikającego świata wsi na południu Francji z wsiami w Algierii (Gouirir 2007). Sam Bourdieu w publikacji dotyczącej zmarłego Sayada wspomina o tym w następujący sposób:

Zabrałem go do mojego domu rodzinnego w miasteczku w Pirenejach, gdzie prowadziłem badanie na temat samotnych starszych osób z rodzin rolniczych i on natychmiast zrozumial [...] i w ten sposób pomógł mi w zrozumieniu powodów mojego zainteresowania rolnikami w Kabylii. To stworzyło między nami (moi rodzice bardzo go lubili) pewien rodzaj prawdziwej relacji rodzinnej ${ }^{23}$ (Bourdieu 1998).

Quasi-rodzinne relacje są cechą charakterystyczną więzi, które występują między partnerami sprzężenia karier. Umożliwiają one redukcję dystansu, co z kolei gwarantuje wyjątkowo wysoką jakość współpracy (aczkolwiek, jak wskazuje słusznie inny partner sprzężenia kariery z Bourdieu - Passeron - relacje przyjaźni w pewnych przypadkach moga paraliżować postęp prac naukowych ${ }^{24}$ ). Rola Sayada - przyjaciela i „brata” - zawierała trudno uchwytne, choć kluczowe elementy pracy naukowej, jak prowadzenie rozmów na pewne tematy, w których trakcie dokonuje się analizy zebranego materiału. Ale nie tylko: można także wskazać na bardzo konkretne i namacalne czynności. Bourdieu wspomina o ponad setce wywiadów zrealizowanych wspólnie z Sayadem. Gdzie jest ślad wkładu algierskiego socjologa w publikacjach powstałych na podstawie materiału „wspólnie zbieranego i wspólnie analizowanego" ${ }^{25}$ (Bourdieu 1998)?

Poza jedna książka autorstwa tandemu socjologów (Le Déracinement 1964) i dedykacja kolejnej pozycji, tym razem podpisanej jedynie przez Bourdieu (Trayy sælkice...), czytelnik nieznający kulisów życia i pracy wielkiego

\footnotetext{
${ }^{23}$ „Je l'avais emmené chez moi, dans mon village des Pyrénées, où je menais l'enquête sur les causes du célibat des aînés des familles paysannes et il avait compris aussitôt, m'aidant ainsi à le comprendre moi-même, [...] les racines de mon intérêt pour les paysans kabyles. Cela avait créé entre nous (mon père et ma mère l'aimaient beaucoup) une sorte de vrai lien de famille" (Bourdieu 1989).

${ }^{24}$ „Obserwowałem często $\mathrm{w}$ relacjach intelektualnych istnienie jednego negatywnego efektu będącego konsekwencją uczucia przyjaźni, które hamuje konfrontację naukową. Bourdieu i ja byliśmy bardzo długo zażenowani unikami, jakich dokonywaliśmy w naszych wzjemnych odpowiedziach dotyczących najbardziej sprzecznych aspektów prac napisanych wspólnie. [...] Bourdieu i ja przez trzydzieści lat unikaliśmy wzajemnego cytowania się, aby nie podejmować ryzyka wzajemnego mnożenia polemik notowanych w odsyłaczach, które tak bardzo lubiliśmy obaj wykorzystywać” (Passeron 2005: 80-81). ${ }^{25}$ Podkreślenie autorki.
} 
socjologa francuskiego niewiele znajdzie o Sayadzie ${ }^{26}$. Dedykacja na ogół nie oznacza, iż jest się współautorem chociaż części pracy... W swej „nieautobiografii” Bourdieu wspomina Sayada jedynie w odniesieniu do dwóch sytuacji (nazwisko jego pojawia się cztery razy w wersji francuskiej, pięć - w angielskiej w 141-stronicowym dziele, które niemalże w połowie traktuje o Algierii) ${ }^{27}$. Opowiadając o zdarzeniu, które ilustrowało ciagła obecność autora w terenie i jego pasję dla mieszkańców tej części Afryki (kilka stron umieszczone w nawiasie), Bourdieu podaje w kolejnym nawiasie przykład obrazujacy te działania (tego nawiasu nie ma w wersji angielskiej, w której Sayad jest wymieniony dwukrotnie, a nie raz, jak w oryginale: pierwszy raz tłumacze dodali jego nazwisko, ponieważ, jak przypuszczam, tekst był niejasny). Bourdieu w tym fragmencie i w innych także - opowiada o sobie, jakby był sam na algierskim odludziu: nagle jest niebezpieczna sytuacja, która zostaje zdezamortyzowana dzięki Sayadowi. Ten ostatni nie jest czytelnikowi przedstawiony - nie wiadomo, o kogo chodzi. Bourdieu wspomina jedynie, że towarzyszący mu Sayad, jako Algierczyk, ryzykował prawdopodobnie o wiele więcej niż francuski socjolog (Bourdieu 2004: 65). Kilka stron później, przy okazji pochwał skierowanych pod adresem anonimowego studenta, czytelnik dowiaduje się, że Sayad to także student Bourdieu i działacz na rzecz wyzwolenia (Bourdieu 2004: 71). Następnie autor autoanalizy opowiada o kolejnej sytuacji badania w terenie wojennym, informujacc o nocnym przepisywaniu notatek z obserwacji wraz z Sayadem (Bourdieu 2004: 73). To zdanie

\footnotetext{
${ }^{26}$ W zbiorowej pracy kierowanej przez Bourdieu La Misère du Monde (1993) Sayad napisał cztery rozdziały. Udział Sayada w tej publikacji jest uzasadniony dwoma czynnikami. Pierwszy dotyczy powszechnego postrzegania problemów społeczeństwa francuskiego, biedy i wykluczenia jako nierozerwalnie związanych z kwestiami populacji emigrantów (oczywiste wydaje się w świetle tego postrzegania, że ta problematyka zajęła pokaźne miejsce w La Misère du Monde). Drugi aspekt jest powiązany z wyborem eksperta w tej dziedzinie: Sayad był wtedy nie tylko jednym z najlepszych specjalistów od emigracji północnoafrykańskiej, a zwłaszcza algierskiej (uważanej za główne zagrożenie dla bezpieczeństwa francuskiego społeczeństwa), ale także jednym z niewielu specjalistów badających populacje migrantów od wielu lat.

${ }^{27}$ Powyższe spostrzeżenie różni się od pierwotnej wersji, w której napisałam, iż Bourdieu wspomina tylko raz o Sayadzie. Cały fragment opisujący przedstawienie roli Sayada w algierskich pracach, zawarte w ostatniej książce Bourdieu (Bourdieu 2004), zmodyfikowałam po uwadze Marcina Serafina, za którą serdecznie mu dziękuję. Odpowiedzi na jego pytania, które powstały w wyniku konsultacji tekstów angielskojęzycznych (tłumaczeń), uwypukliły jeszcze bardziej technikę zacierania śladów współpracy, polegająca na spłyceniu różnych form kooperacji, a także na pewnych zabiegach tłumaczy (likwidacja nawiasów), które zmieniają wydźwięk tekstu - mimo że są to pozornie drobne zmiany, to, analogicznie do graficznych uwypukleń, modyfikują w pewnym stopniu natężenie danej wypowiedzi (Pontille 2004). Podobnie umieszczanie Sayada wśród innych współpracowników algierskich, bez dodatkowych wyjaśnień, jest idealnym przykładem techniki zacierania (analogicznej do opisanego przez de Singly'ego mechanizmu ujednolicania odrębnych kategorii w celu spłaszczenia form współpracy, które w efekcie powodują konfuzję - patrz w dalszej części artykułu).
} 
stanowi najbardziej konkretny przekaz (oprócz opowiadań na temat stałego przemieszczania się) dotyczący ich współpracy. Ostatnie wspomnienie jest znowu w nawiasie: mowa tutaj o wielkiej podporze - immense soutien - w konstruowaniu interpretacji zdarzeń algierskich. Tutaj Sayad zostaje „utopiony” wśród siedmiu innych nazwisk studentów algierskich. Nigdzie nie jest powiedziane, jaką właściwie rolę Sayad odegrał w tym okresie.

Sayad tymczasem był cieniem Bourdieu w jego latach algierskich - towarzyszył mu nieomal we wszystkich przedsięwzięciach badawczych. Pomimo jego kluczowej roli, Bourdieu wspominał o Sayadzie jako o swym informatorze, przyjacielu i współpracowniku - dzieląc z nim autorstwo tylko jednej książki, podczas gdy na podstawie badań prowadzonych wspólnie $\mathrm{z}$ algierskim socjologiem powstało ich kilka (Tray szkice, Le bal de célibataires). Kolejne książki napisane na podstawie prac algierskich zostały opublikowane wiele lat później (zmienił się klimat intelektualno-polityczny we Francji i można było publikować teksty, które nie popierały oficjalnej wersji relacji z lat 50. i 60. o utraconych terytoriach francuskich). Wszystkie publikacje, z wyjątkiem jednej pracy zbiorowej, sa już podpisywane przez samego Bourdieu ${ }^{28}$.

Z czasem zbudował on swą markę Bourdieu \& Co. (spółka „Bourdieu”, jak podkreśla wielu socjologów francuskich - de Singly, Grignon, Villette, Passeron $i$ in.) i wkład innych w jego prace widnieje sporadycznie w pojedynczych autorskich rozdziałach, które „uzupełniaja” główną zawartość autoryzowana przez mistrza, lub najczęściej w formie podziękowań. A Sayad nie był jedynie współpracownikiem „technicznym” - człowiekiem z cienia. W przeciwieństwie do powszechnej i obowiązującej w epoce jego działalności tendencji pisał on o emigracji w odmienny sposób. Jego artykuły stanowią do dziś podstawę studiów migracyjnych (np. publikacja dotycząca trzech fal migracyjnych z 1977 r.). Zauważał wielkie różnice w populacjach migrujących i w roli migrantów. Jak sam podkreślał, używając cytatu uczestnika jego badań: „przedtem migranci przyjeżdżali, aby produkować dla Francuzów, a teraz aby produkować Francuzów" (w nawiązaniu do roli demograficznej). Dokonał znaczących odkryć w pracach nad populacjami migrującymi zarówno w odniesieniu do relacji migrant - państwo, jak i do nowatorskiego - jak na lata 70. - transnarodowego traktowania kwestii migracji (nie używając terminu „transnarodowy”, wskazywał na zawieszenie migrantów w przestrzeni pozanarodowej i ,wypychanie” ich w obu krajach - emigracji i imigacji - na pozycje „nieobecnego”).

\footnotetext{
${ }^{28}$ Mowa tutaj o wspomnianej wyżej książce Travail et travailleurs en Algérie, 1963. Ukazał się też jeden wspólny artykuł Bourdieu i Sayada w „Etudes Rurales” nr 12 (czasopismo o małym zasięgu).
} 
Opisał też emocjonalne strony sytuacji emigranta, skazanego na wieczne cierpienie z powodu nieskończonej tułaczki (począwszy od lat 80.). Jego koncepcja - i tytuł książki: Podwójna nieobecność (La Double Absence; Sayad 1998) - stanowi nie tylko adekwatny obraz procesów migracyjnych, ale także istotny wkład w rozwój badań nad migracjami, który jest niezwykle oddalony od francuskich modeli przyjmowania emigrantów i integracji poprzez skolaryzację i wpajanie ideałów republikańskich. Mimo tych znaczących osiagnięć i nowatorstwa prace Sayada są mało znane nawet we Francji. Bourdieu obiecał zająć się spuścizną swego przyjaciela. Nie zdążył czy po prostu nie miało to dla niego znaczenia? Ich relacja jest określana przez wieloletnich bliskich współpracowników jako „decisive non moinproblematique" ${ }^{29}$ (Laacher 2010) ${ }^{30}$. W mowie wygłoszonej na konferencji poświęconej algierskiemu socjologowi Smain Laacher, który przez wiele lat pracował z Sayadem w jednym pokoju, wielokrotnie ma kłopoty z określeniem tej relacji, pełnej napięć i owianej tajemnica. W trakcie wymiany korespondencji (zainspirowanej chęcią pogłębienia opisywanych w niniejszym artykule kwestii) z jednym z najbliższych współpracowników Sayada i Bourdieu, który pragnie nie ujawniać swojego nazwiska, dowiedziałam się, że na razie jeszcze jest to temat tabu - zbyt mało czasu upłynęło, aby mówić swobodnie o tych sprawach: „niemniej jednak z pewnością można stwierdzić, że relacja ta była zdominowana relacją kolonialna, jaką Francja i Francuzi utrzymywali z Algierią i Algierczykami” (korespondencja prywatna). Trudno mówić o typowej relacji kolonialnej jako „normalnej” dla tego okresu - z pewnością nie większościowo reprezentowanej przez środowiska intelektualne i uniwersyteckie. Sayad nie tylko

\footnotetext{
${ }^{29}$ Archiwum dźwiękowe http://www.histoire-immigration.fr/podcast/univercite_2009/20100318/ laacher_20100318.mp3.

${ }^{30}$ Krótko po śmierci Sayada Bourdieu wydał w swej kolekcji „Liber” książkę zatytułowaną La Double Absence (1999). Był to zbiór uprzednio opublikowanych artykułów, zredagowany w jedną całość. Redakcją i skromnym wstępem (cztery strony) zajął się Bourdieu. Z podziękowań zamieszczonych w tym dziele, złożonych przez Rebeccę Sayad - wdowę po autorze (zostały one napisane tuż po jego śmierci), można wnioskować, iż Bourdieu zrobił wiele - wydał książkę. Niemniej jednak, można było oczekiwać większego zaangażowania Bourdieu w udostępnienie spuścizny po Sayadzie kolejnym pokoleniom badaczy. Ponad 10 lat, do 2009 r., archiwa i materiały z badań Sayada czekały na opracowanie, archiwizację i skład w miejscu publicznym. Obecnie w Muzeum Historii Imigracji w Paryżu znajduje się 31 metrów bieżących półek z dokumentami, notatkami, transkrypcjamii wywiadów, artykułami, tekstami i kasetami z wywiadami - dokumenty gromadzone w ciagu całego życia. Najstarsze pochodza z prac realizowanych jeszcze przed spotkaniem z Bourdieu. Można więc wnioskować, że Sayad miał już pewne doświadczenie w badaniach terenowych, gdy dostał propozycję debiutującego jako etnolog Bourdieu. Można przypuszczać, że właśnie o opiekę i udostępnienie społeczności naukowej tego materiału chodziło Sayadowi, gdy tuż przed śmiercią prosił o zajęcie się jego spuścizną. Bourdieu przejęcie tych archiwaliów nie sprawiłoby żadnych trudności - był osobą nr 1 francuskiej socjologii. Nie zrobił tego... Archiwum powstało dzięki staraniom współpracowników Sayada i jego uczniów (przy współpracy z wdową Rebecca).
} 
„bardzo długo, zbyt długo pozostawał w niepewności i zagrożeniu zawodowym" (Laacher 2010), ale także jego wkład w prace algierskie Bourdieu został zminimalizowany (jak zostało opisane wcześniej). Dopiero po jego śmierci nastapił wzrost zainteresowania Sayadem: we Francji organizuje się wiele konferencji, powstało też wiele publikacji poświęconych temu socjologowi. Od momentu otwarcia jego archiwów można mówić o wielkim zainteresowaniu spuścizną tego dwukulturowego uczonego.

Jak sugeruje omawiany przypadek, trzeci okres sprzężenia karier nie zawsze sprzyja wzmacnianiu reputacji obu partnerów - czasami korzysta tylko ten, który w spektakularny sposób buduje swą karierę za pomoca kolejnych-udanych-sprzężeń. Przed przystapieniem do analizy następnego przypadku intensywnej współpracy warto dokładniej przyjrzeć się typowi relacji, jakie Sayad i Bourdieu utrzymywali ze swoimi współpracownikami.

\section{Patron czy partner? Dwa skrajne modele relacji współpracy w nauce}

$\mathrm{Na}$ temat współpracy między Bourdieu i Sayadem napisano niewiele, dysponujemy natomiast licznymi opisami sposobu pracy obu socjologów, pozostawionymi przez ich wieloletnich współpracowników. Sugerują one istotne różnice $\mathrm{w}$ relacjach obu socjologów z ich partnerami naukowymi. Opisywane przypadki można uważać za skrajnie różniące się od siebie i warto je poddać analizie ze względu na fakt, że te odmienne typy relacji między członkami zespołów badawczych są praktykowane w środowiskach naukowych powszechnie. Można przypuszczać, że różnorodność występujących typów funkcjonowania zespołów zawiera się w przestrzeni między tymi opisanymi przypadkami.

Większość przytoczonych fragmentów została napisana po śmierci obu uczonych (ale nie wszystkie). Książka zatytułowana Pracować z Bourdieu (Travailler avec Bourdieu 2003) jest publikacja pokonferencyjną (uroczystość zorganizowana po śmierci Bourdieu) i liczy ponad 300 stron. Mimo takiej objętości zawiera bardzo niewiele informacji na temat, który obiecuje poruszać. Większość autorów opisuje, jak korzystali - w sposób pozytywny lub negatywny $-z$ teorii stworzonych przez Bourdieu, a opowieści o codziennej pracy jest niewiele, mimo że niektórzy autorzy mieli kilkunastoletnie doświadczenie nieomal codziennego z nim obcowania. Artykułów poświęconych Sayadowi jest wiele (sa to także teksty napisane po jego śmierci), aczkolwiek nie zostały wydane w formie książki; publikacje umieszczono w specjalnym numerze pisma dotyczącego emigracji, a także na stronie internetowej. Pojedyncze świadectwa znajdujemy też w różnych 
czasopismach socjologicznych i antropologicznych. W nich, przeciwnie, dominuja dokładne opisy konkretnych sytuacji pracy, postaw algierskiego socjologa czy też relacji, jakie utrzymywał ze swoimi kolegami. Konkretne przykłady dotycza jego wywodów (pozornie zdezorganizowanych, ale doskonałych $\mathrm{w}$ prowadzeniu argumentacji i bardzo przekonywujacych). Zawierają także zapisy dotyczące redakcji tekstów: tworzenia kolejnych wersji, poprawiania prawie bez końca. Współpracownicy Sayada nie mieli wrażenia, że łatwo się z nim pracuje, nie byli jednak wykorzystywani i wolno im było myśleć inaczej! (Temime 1999: 266). To ostatnie zdanie silnie kontrastuje z licznymi wspomnieniami o Bourdieu, któremu zarzuca się autorytarne zmuszanie do przestrzegania $z$ góry narzuconych ram teoretycznych, a także wykorzystywanie współpracowników (do tych kwestii powrócę w dalszej części artykułu). W świadectwach o Sayadzie często porównuje się obu socjologów, a typowym zestawieniem jest następujący fragment:

P. Bourdieu pracuje zawsze ze swoim zespołem, większym lub mniejszym. Jego publikacje stanowią obiekt dużego rozgłosu i często sąźródłem polemik. [...] A. Sayad pracował sam lub z kilkoma jedynie współpracownikami, budując swe interpretacje zawsze w sposób bardzo dyskretny i regularny. Ukazywał fragmenty wydłużonych wywiadów ze swoimi respondentami, dbał o wyłonienie wszelkich aspektów dotyczących danej osoby bez cienia oceny, a przede wszystkim bez popadania w tani dyskurs na temat biedy czy populizmu (Gouirir 2007: 21).

Często powraca uwaga na temat egalitarnych czy też partnerskich relacji między wspólpracownikami w ekipie algierskiego naukowca:

Abdelmalek Sayad bez fałszywej skromności odrzucał możliwość utrzymywania wszelkich relacji typu mistrz - uczeń. Uważał, że w niczym nie przypominał mistrza z tego powodu, że właśnie ,uprawianie socjologii - socjologii tego, co się robi" zobowiązuje nas do permanentnego kwestionowania swych działań i uniemożliwia usytuowanie siebie samego w relacji klasycznej - na przykład hierarchicznej typu mistrz - uczeń. Było to niemożliwe, ponieważ on się uważał za wiecznego ucznia (Chaib 2000).

Cytowany fragment zdecydowanie różni się od sprawozdań dotyczących relacji, jakie panowały w zespole Bourdieu. Claude Grignon, wieloletni bliski współpracownik Pierre’a Bourdieu, w następujących słowach opisuje działalność Centre Sociologie Européenne (CSE), zespołu badawczego kierowanego przez Bourdieu:

Historia Centrum nie jest wyjątkowa. Jeżeli chcemy, aby była informatywna, a nie hagiograficzna, to należy skoncentrować się na banalnych sprawach i usytuować ją w rodzinie przypadków, do której przynależy. Ślady i mechanizmy sekciarskie, które były u podstaw tego naszego 
przedsięwzięcia, można znaleźć w większości małych społeczności intelektualnych, których nieuległość prowadzi do odcięcia od świata. To odnajduje się w heterodoksyjnych szkołach, awangardzie literackiej czy też grupach rewolucyjnych. [...] Centrum cechowała rygorystyczna hierarchia, w której dwie reguły hierarchizowania spotykały się na szczycie w postaci swego szefa. Hierarchia widoczna, posiadająca legitymizację, oczywista i wyjaśniona, która reprodukowała w sposób ścisły szkolną hierarchię opartą na dyplomach i dyscyplinach. Rozróżniała ona normaliens ${ }^{31}$ od nie-normaliens, tych $z$ agregacja $i$ bez, tych $z$ agregacja $z$ filozofii $i$ innych dyscyplin. Ta oficjalna hierarchia (był nawet napisany regulamin) była zdublowana przez równoległa hierarchię „zwyczajową”, opartą na stażu przynależności do grupy, poręczycielstwie (wejście do Centrum przez Z, a nie przez Y, znaczyło bycie nowicjuszem na długi okres) i przede wszystkim zbudowaną na bliskości, quasi rodzinnych stosunkach, intymności osobistej z liderem grupy (Bourdieu). Podobnie jak w pensjonatach czy internatach, a także w politycznych grupach subwersywnych, uwielbiano w Centrum sekrety czy tajemnice, a nawet pewne „podziemne” zachowania. Informacja była rzadkościa, rozprowadzanie jej było środkiem intergracji i próbą dla tych, którym to zlecano; jej rozpowszechnianie podlegało ścisłej kontroli. Wznieść się na szczeble hierarchii Centrum znaczyło dotrzeć wcześniej do tajnej informacji (lub przekazanej jako tajnej) - takiej, której nadawano podwójny sens terminu zachować - zachować w pamięci i dla siebie. Najważniejsze sprawy rozgrywały się między wtajemniczonymi: nie w ramach zebrań roboczych, ale w rozmowach kuluarowych w Centrum. Jeszcze ważniejsze były niekończące się konwersacje telefoniczne, które P. Bourdieu uprawiał $z$ wtajemniczonymi (intimes). Zgodnie $z$ najbardziej tradycjonalnym genderowym podziałem pracy ta domowa hierarchia odbijała się na kobietach, [...] wokół Bourdieu kobiety były oddelegowane do funkcji podrzędnych (subalternes), ale strategicznych - nadzorowały przestrzeganie hierarchii; były także powiernicami i pocieszycielkami (Grignon 2002: 195).

Powyższy obszerny fragment koreluje z licznymi ilustracjami dotyczącymi funkcjonowania zespołu badawczego, którym Bourdieu kierował od 1968 r. (a nieformalnie już od powrotu z Algierii, kiedy był sekretarzem Centrum założonego przez Arona) aż do przekazania go (po fuzji z Centrum Edukacji i Kultury) w 1997 r. swojemu uczniowi Remiemu Lenoirowi.

Ostatnia podkreślana różnica między Sayadem a Bourdieu dotyczy eksponowania własnej osoby i pracy nie tylko w środowisku naukowym, ale także poza nim. Sayad „miał doskonałą świadomość własnej wartości, ale nie «rozprzestrzeniał się» w mediach, ani nawet w prasie specjalistycznej. Jego

\footnotetext{
${ }^{31}$ Absolwenci École Normale Supérieure.
} 
lista publikacji, bardzo często cytowanych, a jeszcze częściej kradzionych ${ }^{32}$, może się wydawać nieuważnemu czytelnikowi krótka" ${ }^{33}$ (Temime 1999: 265). Bourdieu wręcz przeciwnie. Nie tylko eksponował swe prace i przekonania teoretyczne w środowisku naukowym, ale i poza nim (media). Przede wszystkim sedno problemu leży w tym, że przez wiele lat skutecznie (świadomie lub nie) zacierał (gommé) wkład swych współpracowników, ich dokonania, a nawet po prostu współpracę - wzmacniając swą pozycję (obszernie na temat tej praktyki pisał także de Singly w 1989 r., bazując na analizie referencji używanych, a raczej przemilczanych przez Bourdieu). Dalsza część artykułu jest poświęcona analizie tego szczególnego mechanizmu zacierania, dzięki któremu przekonanie o geniuszu Bourdieu zostało skonstruowane i jest utrzymywane w pewnych kręgach po dziś dzień.

\section{/// Gra dominacji: kolejne współprace, kolejne sprzężenia i trans- formacja kapitałów}

„Innymi słowy - używając koncepcji Bourdieu dotyczącej «kapitału społecznego relacji» («Actes de la Recherche» 1980, nr 31) - strategie, świadome lub nieświadome, wdrożone przez Bourdieu w celu zaprezentowania się w roli jedynego (także w roli niezrozumiałego czy niesprawiedliwie atakowanego) sprawiają, że ten socjolog wie, jak używać najlepiej dóbr rodzinnych gromadzonych przez innych - przekształcając je w kapitał symboliczny: quasi zmonopolizowany na osobie stojącej na świeczniku (celebrycie)" 34 (de Singly 1998).

François de Singly w 1989 r. w artykule zatytułowanym Bourdieu - kolektywne przedsiebiorstwo pod prywatnym nazwiskiem (Nom propre d'une entreprise collective) podkreśla:

Co jest uderzające, to amnezja dotycząca decydującego wymiaru w pro-

dukcjach Bourdieu, jakim jest wymiar pracy zespołowej (de Singly 1998).

Po doświadczeniach pierwszej pracy terenowej Bourdieu kontynuuje swa działalność, otoczony licznymi współpracownikami. Ich widoczność - nawet tych, którzy są partnerami w procesie sprzężenia karier i dzięki

\footnotetext{
${ }^{32}$ Kradzionych w sensie plagiatu pomysłów.

33 „Il avait parfaitement conscience de sa valeur, mais il ne «s'étalait» pas dans la presse, ni même dans les revues spécialisées. Et sa production, souvent citée et, plus souvent encore, pillée, peut paraître courte à un lecteur superficiel" (Temime 1999: 265).

34 „Pour l'exprimer autrement, et en reprenant un concept de Bourdieu - celui de «capital social de relations» («Actes de la Recherche» 1980, nr 31) - les stratégies, conscientes ou non, mises en œuvre par Bourdieu pour se présenter seul (y compris sous la figure de l'incompris, de l'injustement attaqué) font que ce sociologue sait utiliser comme il faut les biens de famille, accumulés par les autres en les convertissant en capital symbolique: une célébrité quasi monopolisée” (de Singly 1998).
} 
którym Bourdieu buduje swoją karierę i swoiste imperium socjologiczne (dzięki ich pracy i swojej własnej) - podlega specyficznemu mechanizmowi zatarcia. Podobnie jak w przypadku Sayada, wpływ innych bliskich partnerów Bourdieu zostaje usuwany w cień. Przypadek Jean-Clauda Passerona będzie poruszany w końcowej części artykułu w nawiązaniu do Les Héritiers, ich wspólnego dzieła, które okazało się wielkim sukcesem.

Natomiast funkcjonowanie mechanizmu usuwania w cień kluczowych współpracowników przedstawię na podstawie analizy najistotniejszego elementu karier naukowych - publikacji: w tym przypadku tych, które powstały na bazie wspólnych badań (lub badań zrealizowanych przez współpracowników). Analizowany proces ma wiele różnorodnych odmian i kilka z nich zostanie poniżej opisanych. Pierwszą jest indywidualne autoryzowanie pracy zbiorowej.

\section{Zacieranie śladów współpracy A: publikacja indywidualna pracy zbiorowej - przypadek La Noblesse d'État}

Wybranym przypadkiem jest publikacja powstała głównie we współpracy z Monique de Saint-Martin, ale także $z$ innymi osobami. Jest to zbiór zespołowych prac badawczych realizowanych w ciagu 20 lat, które zaowocowały wydaniem La Noblesse d'État. Druga połowa lat 60. (1966 - początek badań Bourdieu, Passerona, de Saint-Martin i in. nad edukacja francuskich elit), lata 70. i 80. są okresem intensywnej działalności CSE, a następnie Centrum Socjologii Edukacji i Kultury-CSEK. Był to czas realizacji badań socjologicznych prowadzonych na szeroką skalę: wielkie ankiety statystyczne, masowe serie wywiadów, analiza archiwów, gigantyczna praca badawcza kilkudziesięciu osób prowadzona pod kierunkiem Bourdieu i Passerona, a następnie samego Bourdieu (Monique de Saint-Martin była jego zastępcą w CSEK w latach 1985-1995). Zarządzanie tak dużą liczbą projektów wymaga wielkiej sprawności organizacyjnej - Bourdieu był z pewnością świetnym dyrektorem operacyjnym CSE/CSEK.

Jednym $z$ kluczowych aspektów pracy naukowej są publikacje wyników prac, a co się z tym wiąże, dystrybucja ich autorstwa (zob. Pontille 2003). W dyscyplinach, w których pracują duże zespoły (np. fizyka, biologia), wykształcono pewne zasady regulujące przyznawanie autorstwa. Oczywiście funkcjonuje równolegle wiele różnych sposobów dystrybucji autorstwa. Ponieważ jest to proces interakcyjny, opierający się na negocjacjach między stronami, można zaobserwować liczne odstępstwa od ogólnie 
przyjętych zasad, ale pewnym jest, że poszczególne środowiska wypracowały ramowe reguły postępowania (Pontille 2003). Zakładają one, że nazwisko lab-leadera jest zawsze umieszczane w grupie autorów, często jest on tzw. adresem do korespondencji (co jest związane z mobilnością członków ekip: lab-leader jest osobą, która zostaje na ogół najdłużej w danej instytucji). Natomiast tzw. pierwszym autorem pracy jest zawsze osoba (lub osoby), która(e) odegrała(y) kluczową rolę w realizacji badania. Oddając artykuł czy książkę do publikacji, opisuje się wkład danej osoby w taki sposób, aby nie ulegało wątpliwości, kto jest twórcą koncepcji, kto przeprowadził badania, a kto redagował końcowy tekst.

W naukach społecznych, z powodu naszego powinowactwa $z$ humanistycznymi (w końcu na takim gruncie się one wykształciły), mamy tradycję podziału pracy, w której największą wagę przywiązuje się do redakcji tekstu, ponieważ najczęściej w trakcie pisania dokonuje się analizy badanego problemu. Niemniej jednak w przypadku badań będących podstawą La Noblesse d'État (podobnie jak w przypadku Reprodukcïi czy Dystynkcji), odmiennie niż w innych, głównie teoretycznych pozycjach sygnowanych przez Bourdieu, cała istota analizowanej tutaj publikacji leży w empirycznej podstawie tego dzieła. Ogrom pracy - ponad dwadzieścia lat badań - grupy socjologów realizujących swe własne projekty ${ }^{35} \mathrm{w}$ ramach tego olbrzymiego jak na tamte lata przedsięwzięcia staje się dorobkiem anonimowych pracowników. Informacja o ich wkładzie w książkę zostaje zepchnięta do odsyłaczy lub wzmianek pisanych małym drukiem. Oto kilka przykładów tego typu techniki „wymazywania”.

We wstępie do La Noblesse d'État nie ma informacji o osobach, których badania były podstawą tej książki; nie można tam także znaleźć podziękowań tym osobom, których praca stanowi o wartości (wcale nie dodanej, ale podstawowej) analizowanej pozycji. W pierwszej części La Noblesse d'État odsyłacz przy tytule Les formes scolaires de classifications informuje nas (maleńką czcionką, prawdopodobnie nr 8: „Pierwsza wersja tej części została napisana we współpracy z Monique de Saint-Martin” [Bourdieu 1989: 17]). Część ta (jej pierwsza wersja), napisana wspólnie, liczy 80 stron na 561 całej publikacji (w tym 153 strony aneksu, czyli 408 stron tekstu). Druga część książki powstała na bazie badań zrealizowanych również przez Monique de Saint-Martin wraz z inną partnerką sprzężenia karier z Bourdieu: Yvette Delsaut. Obie prowadziły prace badawcze w prestiżowych liceach

\footnotetext{
${ }^{35}$ Nierzadko są to „życiowe” badania - czyli nie tylko realizowane jako podstawa doktoratu, ale takie, które zajmują większość kariery i stanowią pewną specjalizację i pole ekspertyzy, jak można zauważyć na podstawie analizy karier Boltanskiego, Passerona, de Saint-Martin, Chapouliego czy Villetta.
} 
francuskich w 1968 r. Kolejne badania zostały zrealizowane w 1972 r. przez Jean-Michela Chapouliego i Dominique'a Merlliego (dotyczyły one profesorów szkolnictwa średniego). Pierwszy rozdział części trzeciej - kolejne 79 stron - został także napisany we współpracy z Monique de Saint-Martin (tym razem nie tylko jako pierwsza wersja tekstu) - oczywiście informacja ta jest zawarta w odsyłaczu. Następnie w czwartej części rozdział drugi - czyli znowu 56 stron napisanych razem z Monique de Saint-Martin (zaznaczone znowu przypisem dolnym). Suma stron napisanych wspólnie jest równa 215 na 408 stron tekstu - to wcale nie tak mało! Ponad połowa pracy oficjalnie (aczkolwiek współautorka jest zepchnięta do przypisów) powstała we współpracy. Dodatkowo, pozostałe rozdziały zawieraja także pracę Monique de Saint-Martin i innych osób. A książka jest podpisana tylko jednym nazwiskiem - Bourdieu - bez adnotacji, że jest on redaktorem, a nie autorem całości. Jak to jest możliwe?

W tym miejscu należy przypomnieć, że w środowiskach zajmujących się nauką osiagnięcia nie są przypisywane firmie czy grupie badawczej, ale jednostce (jednostkom). Reputacja instytucji, w której pracuje jednostka, jest uzyskiwana dzięki kumulacji indywidualnych „reputacji”. A Bourdieu w La Noblesse d'État zrobił dokładnie odwrotnie: pracę wielu autorów podpisał jednym (własnym) nazwiskiem. Skutkiem tego były liczne reakcje najbliższych współpracowników tego autora, którzy do nazwiska Bourdieu dopisywali „\& Co.” (de Singly 1998; Villette 2008). Eksponując własny wkład w kolektywna pracę, autor Esquisse pour une auto-analyse mobilizował kapitał (nie tylko symboliczny, ale także ekonomiczny) pod stworzona przez siebie marką. Użycie własnego nazwiska do określenia firmy, którą się kieruje, jest praktyką stosowaną powszechnie - także w nauce (każdy z nas potrafi podać przykłady z własnego otoczenia ilustrujące tego typu mechanizmy). Niemniej jednak Bourdieu opanował tę technikę do perfekcji. De Singly uważa, że świetnie potrafił przekształcić kapitał społeczny (praca jego współpracowników) we własny kapitał symboliczny (zob. motto do tego rozdziału - de Singly 1998). W końcu teorię kapitałów i ich wzajemnej przekształcalności znał Bourdieu jak nikt inny! W jaki sposób dochodziło do tego, że owoc pracy grupowej podpisywał jako jedyny autor? 


\section{Zacieranie śladów współpracy B: \\ destylacja autorstwa w stosunku do proporcji potencjalnych czytelników}

Proces zacierania wkładu pracy partnerów sprzężenia i innych współpracowników odbywa się stopniowo w czasie. Najpierw realizowane są prace badawcze i analityczne - odbywają się one zespołowo. Następnie redagowane są teksty zawierające wyniki badań i ich interpretacje. Otóż dobór autorów figurujących na publikacji nie jest zależny od wkładu osób, które w jakiś sposób uczestniczyły w produkcji danych, ich analizie czy też redakcji tekstu końcowego. Liczba autorów (i ich wybór) zależna jest od zasięgu danej publikacji. Reguła zacierania polega na stosowaniu odwrotnie proporcjonalnego stosunku między zasięgiem pracy a liczbą autorów!

Przykład: na podstawie analizy publikacji zrealizowanych w CSEK w latach 70. i 80. wyróżniam trzy główne typy prac: a) raport z badań, b) artykuł w czasopiśmie naukowym (zdecydowana większość publikowana we własnym piśmie CSEK - „Actes de la Recherches en Sciences Sociales”) i c) książki wydawane przez główne wydawnictwa francuskie (największy zasięg). Po tytule i zawartości raportów, artykułów i książek, a także na podstawie informacji na temat specjalizacji badaczy-autorów oraz daty powstania kolejnych prac można stwierdzić, iż poszczególne projekty dawały podstawę do różnych typów publikacji, które oprócz odmiennej formy (inaczej pisze się raport, artykuł i książkę) miały odmienny zestaw autorów (mimo że zawartość w sensie merytorycznym była identyczna $-z$ wyłączeniem artykułu, ze względu na rozmiar tej formy). Tak więc raporty $z$ badań, zawierające wyniki i analizy, sa podpisywane przez osoby zatrudnione w CSEK i pracujące nad danym projektem. Najczęściej jest to kilkanaście nazwisk (rzadziej kilka) figurujących na stronie tytułowej jako równorzędni autorzy (można też spotkać specyfikację uwzględniająca podział pracy: sporządzenie statystyk, redakcja itd.). Tutaj Bourdieu na ogół figuruje tylko jako dyrektor projektu.

Kolejna forma produkcji naukowej jest artykuł. Najczęściej praktykowaną dystrybucja autorstwa jest podpisywanie artykułów przez tandemy, czyli partnerów sprzężenia. Na przykład w latach 1975/1976 w ARSS zostały opublikowane następujące artykuły - Bourdieu z Monique de Saint-Martin o elitach szkolnych i innych kwestiach związanych z bigher education, a także o problematyce poruszanej następnie w Dystynkecji - anatomii gustu; z Lukiem Boltanskim o lingwistyce, o produkcji ideologii dominujacej i o profesorach ze Sciences PO; z Yvette Delsaut o kreatorach mody. 
Te prace, podpisywane wspólnie, dotyczą tak odmiennych terenów badawczych, iż trudno jest przypuszczać, że jedna osoba jest w stanie zdobyć wiedzę i kompetencje konieczne do tego, aby taki artykuł napisać w równoważnej kooperacji. Jeżeli chodzi o prace redakcyjne nad tekstem, to przecież tego typu pomoc na ogół nie oznacza prawa do współautorstwa, ale stanowi część pracy redakcji; oczywiście autor może wyrazić wdzięczność osobie, która dokonała istotnej korekty, w podziękowaniach autorskich ${ }^{36}$.

Książka jest na ogół najobszerniejszą i najbardziej „swobodną” formą produkcji naukowej. Technika zacierania, którą stosował Bourdieu w przypadku książek, została dokładnie opisana na przykładzie La Noblesse d'État. Mimo że autorów jest właściwie wielu (a co najmniej Monique de Saint-Martin z pewnościa jest współautorką tego dzieła), na stronie tytułowej i w referencjach pojawia się jedno nazwisko: Bourdieu. Taka praktyka odnosiła się także do innych książek powstałych na bazie projektów badawczych realizowanych w CSEK. Ponieważ zasięg książek jest odmienny niż zasięg raportów czy artykułów naukowych, trafiały one do szerszej publiczności jako wyłączne dzieło Bourdieu. Jedyny wyjątek od tej reguły dotyczy publikacji zatytułowanej Les institutions de formation des cadres dirigeants (1987). Głównym edytorem była Monique de Saint-Martin, wspierana przez Mihaila D. Gheorghiu. Bourdieu był jednym z 25 współautorów ${ }^{37}$. Wyjątek ten odzwierciedla powszechną organizację pracy w ramach jednego projektu - 25 badaczy. Zespołowa praca wydawnictw (Paris: Ministère de la recherche et de l'espace \& Maison des sciences de l'homme \& CNRS/École des hautes études en sciences sociales) wskazuje na niewielki zasięg tej publikacji (w porównaniu z wydawnictwami typu Seuil czy Minuit).

\footnotetext{
${ }^{36} \mathrm{Na}$ marginesie warto tutaj też przytoczyć uwagę de Singly'ego na temat pomijania wkładu następujących socjologów w produkcję ARSS: „Przez długi czas - dokładnie 87 pierwszych numerów pisma, czyli 16 lat pracy - jedno nazwisko figurowało na kolejnych numerach pisma - Pierre Bourdieu. Nic nie było wspomniane o Claudzie Grignonie, a także o Jean-Claudzie Chamboredonie, czy też o innych, którzy odegrali istotną rolę w «poprawianiu» artykułów” („Pendant longtemps - plus précisément pendant les 87 premiers numéros, soit seize années - le seul nom inscrit a été celui de Pierre Bourdieu. Rien sur Claude Grignon et Jean-Claude Chamboredon qui ont joué un grand rôle dans la «reprise» des articles, ou sur d'autres" [de Singly 1998]).

37 Poza wymienionymi socjologami publikację współtworzyli: I. Bajomi, E. Böhlke, D. Broady, M. Palme, N. Chmatko, M. Haddab, J. Heilbron, O. Henry, M. Ioan, V. Karady, R. Lenoi, M.R. Loureiro, B. Niane, N. Panayotopoulos, M. Pinçon, M. Pinçon-Charlot, D. Robbins, E. Rogg, G. Scarfò, F. Schultheis, M. Vasconcellos, A-C. Wagner, Y. Winkin.
} 


\section{Zacieranie śladów współpracy C: \\ brak kategoryzacji własnych publikacji - bałagan z referencjami}

Opisane dotychczas praktyki zacierania śladów współpracy nie wyczerpuja repertuaru stosowanych technik. De Singly w drobiazgowy sposób analizuje pewien system referencji, praktykowany przez Bourdieu. Otóż, wyróżniając pięć rodzajów publikacji [1. Bourdieu (B) - jedyny autor; 2. B z X; 3. B i X; 4. we wspólpracy z B; 5. pod dyrekcją B], de Singly wykazuje, iż w referencjach do swej poprzedniej książki Bourdieu traktuje te wszystkie publikacje na równi. Zrównując je, dokonuje niejako „podciagnięcia” każdej z publikacji do kategorii „,własnej książki” (de Singly 1998). Zreszta, jak zaznacza Pontille w odniesieniu do praktyk referencjonowania stosowanych przez Bourdieu, to umniejszanie roli współpracy - czy zacieranie - ma także swe odbicie graficzne: nazwiska współpracowników są drukowane na stronie tytułowej mniejsza czcionka (np. książki napisane z Wacquantem; de Singly 1998; Pontille 2004: 51). Można nadmienić, iż znajdziemy w karierze Bourdieu publikacje zbiorowe (La Misere du Monde, 1993) czy też prace pisane we współpracy z ostatnim partnerem sprzężenia Loickiem Wacquantem, co nie zmienia faktu, iż praktyki analizowane w tym artykule były powszechnie stosowane (z czasem stały się one przedmiotem nie tylko kuluarowej, ale także formalnej krytyki środowiska: Verdès-Leroux 1998; de Singly 1998; Grignon 2002; Pontille 2004; Verdrager 2010). Niemniej jednak, przy silnym funkcjonowaniu efektu św. Mateusza jest oczywiste, że współpracownicy „zanikaja” w cieniu wielkiego nazwiska, nawet gdy czasami pojawiają się jako współautorzy lidera.

\section{Zacieranie śladów współpracy $\mathrm{D}$ : zmiana ról - z dyrektora kolekcji na jedynego autora}

Kolejną techniką zacierania jest zmiana roli w podziale pracy. Posłużę się tutaj przykładem publikacji, w której Bourdieu z redaktora tomu staje się autorem książki. Jest to istotna zmiana, jeżeli weźmiemy pod uwagę fakt, iż zawartość dzieła uległa zaledwie niewielkiej modyfikacji. W 1965 r. została opublikowana książka pod tytułem Un Art moyen. Essai sur les usages sociaux de la photographie. W wielu poważnych źródłach bibliograficznych, jak np. strona internetowa Collège de France (najbardziej prestiżowej instytucji naukowej we Francji), w kategorii „Bourdieu jako autor” znajdujemy następujące wyjaśnienie: ,avec [z] L. Boltanski, R. Castel et J.-C. Chamboredon”. Angielska wersja tej ksiażki opublikowana w 1996 r. przez Stanford 
University Press nosi tytul Photography: A Middle-Brow Art. Bourdieu figuruje jako autor ,with Luc Boltanski and Robert Castel”. Kto jest w końcu autorem tej książki? Co się stało z Jean-Claudem Chamboredonem??? Porównując wydanie w języku angielskim $A$ Middle-Brow Art z pierwszym wydaniem francuskim, okazuje się, że Bourdieu jest w oryginale redaktorem tomu, natomiast autorami są Luc Boltanski i Jean-Claude Chamboredon. Niestety, ich nazwiska zostały umieszczone wewnątrz książki, a na tytułowej stronie widnieje nazwisko dyrektora kolekcji: Bourdieu. W konsekwencji wiele bibliografii podaje Bourdieu jako autora. Amerykańska wersja pomija Chamboredona, a przecież wraz z Boltańskim jest jednym z dwóch autorów książki! Jak się okazuje, szczególną okazją do wykorzystania techniki zacierania śladów współpracy jest tłumaczenie dzieła (o tym procesie, nazwanym przeze mnie ,wampiryzacja reputacji”, pisałam w artykule z 2009 r.).

\section{Zacieranie śladów współpracy E: \\ niwelowanie różnic paradygmatycznych ze znaczącymi współautorami}

Umiejętne wskazywanie na brak różnic paradygmatycznych w podejściu obu autorów może być także metodą zacierania wkładu partnera sprzężenia karier we wspólne dzieło. Taki mechanizm opisuje Jean-Claude Passeron w swych wspomnieniach dotyczących jego współpracy z Bourdieu:

PB starał się zawsze w swoich późniejszych badaniach, jak i kolejnych publikacjach, zminimalizować, a nawet zlikwidować dzielące nas sprawy; zacierając te różnice, chciał utopić ten początkowy okres (naszej) współpracy, aby przestał on być istotny w całej trajektorii Pierre’a Bourdieu ${ }^{38}$ (Passeron 2005: 83).

Passeron podkreśla, że w większości w publikacjach dotyczących nauk współczesnych bazujących na argumentach historycznych i opracowaniu pewnych danych powinno się uprawiać współautorstwo. Taki podział prac umożliwia osiagnięcie wysokiej jakości - dzięki negocjacjom współautorów odnoszących się sceptycznie do realizowanych analiz i mniej ulegających własnym przekonaniom co do zasadności użytych (czy też wyznawanych) paradygmatów.

Może właśnie tutaj znajdziemy odpowiedź na pytanie, dlaczego Bourdieu w pierwszym okresie swej działalności uprawiał powszechnie

\footnotetext{
38 „Piere Bourdieu tendait, dans les enquêttes ultérieurs comme dans ses livres minimiser et même à annihiler nos divergeances, gommant les différences comme pour mieux noyer cette période initiale de collaboration dans la trajectoire d'ensemble de Pierre Bourdieu" (Passeron 2005: 83).
} 
współautorstwo, a następnie stopniowo, w miarę uzyskiwania sławy i budowania swego świata teoretycznego, jak wielu wspomina, autorytatywnie zmuszał swych współpracowników do wyznawania tych, a nie innych paradygmatów (de Saint-Martin 2003)? Prawdopodobnie tutaj leży przyczyna (lub jedna z przyczyn - jeżeli nie ograniczamy się jedynie do analizy podziału pracy czy organizacji pracy w jego zespole i dodamy elementy osobowości Bourdieu: zarzucany mu despotyzm, wielkie ambicje czy też nawet pewną megalomanię) łatwego do zaobserwowania procesu stopniowego zaniechania współautorstwa, przy jednoczesnym powiększaniu zespołu badawczego i intensyfikowaniu współpracy z innymi naukowcami!

Bourdieu narzucał model pracy naukowej (jasno sformułowany w Le métier de sociologue), niemniej jednak - jak wszyscy jego współpracownicy od lat 70. podkreślaja - z jednoczesnym narzuceniem własnego systemu paradygmatów, własnego świata teoretycznego (zob. także Lahir 1998). Strzeg1 pilnie aplikacji tych ram myślenia w pełnym przekonaniu o własnej słuszności, że teoria, którą stworzył czy też zmodyfikował i rozpropagował, jest jedyną słuszną podstawą teoretyczną mającą przyczynić się nie tylko do tego, iż socjologia zastapi filozofię i stanie się Nauką XXI wieku, ale także będzie stanowić podstawę dla zmian społeczno-politycznych w przyszłości. Miała to być metateoria.

Oczywiście po analizie wyżej przedstawionych technik usuwania w cień kolejnych, nie tylko dalszych, ale i najbliższych współpracowników nasuwa się pytanie o reakcje zatajonych współautorów na stosowanie tego typu praktyk.

\section{Reakcje partnerów sprzężenia karier}

Wyżej opisane relacje między szefem a członkami zespołu badawczego są absolutnie sprzeczne z ideałem „wolności” przypisanym pracy naukowca (zob. np. role społeczne naukowców, Znaniecki 1984: 463-464). Trudno się więc dziwić, że niewielu współpracowników Bourdieu „wytrzymywało" tego typu podejście do prowadzenia badań naukowych (narzucenie sztywnych paradygmatów). Poza osobami, które poddały się takim warunkom pracy w oczekiwaniu na pragmatyczne rezultaty „bycia Bourdoisien" (możliwość otrzymania pracy, pozycji wykładowcy na uniwersytecie, pewna widoczność wewnątrzśrodowiskowa), naukowcy, którzy prowadzili badania, angażując się w swe prace i postępując według nieformalnego prawa, które daje pełną wolność w analizie danych osobie prowadzącej badanie (wysoki stopień niezależności zawodowej cechuje bowiem pracę naukowca - zgodnie z wyżej wspomnianym ideałem 
„wolności” przekazywanym w trakcie socjalizacji; zob. Wagner 2010), dokonywali niezależnych - a więc niekoniecznie spójnych z linią wytyczona przez Bourdieu - analiz. Zrywali relacje z Bourdieu i odchodzili, tworząc swe własne grupy badawcze, pracując w izolacji bądź porzucając prace naukowe. Tego typu doświadczenia spowodowały, że w latach 90. Bourdieu zyskał sobie przydomek Mandaryna ${ }^{39}$ (najpierw w waskim kręgu, następnie w mediach: Jacques Mandelbaum w „Le Monde”, Bernard-Henri Lévy na łamach gazet itd. ${ }^{40}$ ) - termin ten określa doskonale organizację pracy w centrum, którym kierował.

Należy zaznaczyć, że wielu współpracowników Bourdieu po licznych konfliktach opuszczało Centrum (co nie jest łatwe w systemie organizacyjnym francuskiej nauki: badacz jest „funkcjonariuszem” - pracownikiem państwowym i zmiana miejsca pracy jest niesłychanie skomplikowana). Wielu bez rezerwy opowiadało o swoich doświadczeniach przy okazji spotkań środowiskowych (co nie zawsze było łatwe, biorąc pod uwagę władzę, jaką Bourdieu miał w środowisku francuskich socjologów w latach 80. i 90.). Kilku z nich otwarcie napisało o swych doświadczeniach. Monique de Saint-Martin w rozdziale książki pośmiertnej mówiącej o Pracy z. Bourdieu w następujący sposób uzasadniła swoją decyzję przerwania pracy $\mathrm{z}$,francuskim socjologiem nr 1”:

Przyszedł taki moment w latach 90., w którym zdecydowałam się zarzucić bezpośrednią współpracę z Bourdieu, nie uczestniczyć w projektach, którymi kierował, przestać rozmawiać z nim, zaniechać pytań dotyczących moich własnych badań. Być może dlatego, że forma dominacji i kontroli, która uprawiał, świadomie czy też nieświadomie, nad badaczami i doktorantami, którzy z nim pracowali, stała się przesadna. Być może także dlatego, że stało się coraz trudniejsze wyrażanie wśród członków ekip badawczych, którymi kierował, a także na łamach pisma, które stworzył, „Actes de la Recherche en Sciences Sociales", jakiejkolwiek formy odmiennej od modeli, które w danym momencie starał się on narzucić (Monique de Saint-Martin 2003: 324).

Odpływ współpracowników Bourdieu w kontekście warunków pracy obowiązujących we francuskiej nauce (posady od konkursu po doktoracie aż do emerytury w tym samym miejscu) jest symptomatyczny. Trudno się

\footnotetext{
${ }^{39}$ Mandarynami nazywano w 1968 r. we Francji wykładowców funkcjonujących w ramach feudalnego porządku panującego na uniwersytetach francuskich, przeciwko któremu zbuntowali się studenci [Dziękuję za tę informację Mikołajowi Lewickiemu].

${ }^{40}$ Jacques Mandelbaum: paradoks polega na tym, ,że widzimy tego mandaryna, profesora w College de France, który robi z siebie ofiarę systemu” („Le Monde” 2001, 1 Mai - le droit de reponse). Bernard-Henri Lévy: ,intelektualista jest zawsze, prawie z definicji, «trochę przygłuchawy na sprawy społeczne». Nic mnie bardziej nie irytowało niż postawa Bourdieu, który z wysokiej pozycji mandaryna odgrywał nam rolę «wielkiej Pytii ruchu społecznego»”.
} 
dziwić socjologom, którzy widzieli swą pracę sygnowaną przez szefa zespołu z pominięciem ich własnego wkładu, że decydowali się na taki „desperacki” krok. Oto typowe spojrzenie socjologów francuskich na tę sytuację:

Jego [B.] wspinaczka na szczyty kariery jest zrealizowana za cenę licznych zerwań, bardziej lub mniej brutalnych, z wielką liczbą swych współpracowników najzdolniejszych: J.C. Passeronem, L. Boltanskim, C. Grillonem, J. Verdès-Leroux... (Dortier 2002: 9).

\section{Prawo odległości - dynamika koncentrycznych przestrzeni wiedzy i wiary}

Po kolejnych odejściach i bardziej lub mniej głośnych skandalach stało się tajemnica poliszynela wśród paryskich socjologów, iż produkcja sygnowana nazwiskiem jednego autora jest nieformalnym akronimem obejmującym pracę socjologów zatrudnionych w CSEK. Jeszcze za życia Bourdieu ukazują się analizy jego organizacji pracy oraz publikacje podkreślające, że Bourdieu - o czym wszyscy wiedza - to kilkadziesiąt osób pracujacych latami w CSEK.

Pierre Bourdieu było wyraźnie nazwiskiem określającym pewien podmiot kolektywnej produkcji, podmiot, który zaakceptował poddanie się regule anonimowości (wiemy z teorii dominacji, bliskiej autorowi, że zgoda jest klasyczną oznaką zależności zdominowanych). Czy też, powtarzając za jednym z artykułów tego autora - jego dzieło stało się stopniowo wiarą, której wartość jest taka, że nawet ci, którzy ja oczerniaja, moga z niej skorzystać ${ }^{41}$ (de Singly 1998).

Informacje o takim funkcjonowaniu Centrum mieli współpracownicy i dysydenci już w latach 70. Stopniowo, wraz z dymisjami i kolejnymi „odważnymi” publikacjami demaskującymi specyficzną organizację pracy zespołu Bourdieu, kulisy funkcjonowania CSE stały się powszechnie znane. W końcu lat 90. francuskie środowisko socjologiczne było podzielone na dwa główne obozy - tych, którzy wiedzą i mówia, i tych, którzy wiedza, ale milczą. Tak więc techniki zacierania wiedzy o współpracownikach okazały się skuteczne, zwłaszcza w środowiskach odległych od centrum produkcji wymienianych dzieł. Można pokusić się o sformułowanie pewnej

\footnotetext{
${ }^{41}$ „Pierre Bourdieu était nettement le nom d'une instance de production collective, instance qui acceptait de se plier à cette règle de l'anonymat (on sait d'après la théorie de la domination, chère à l'auteur, que le consentement est un signe classique de la dépendance des dominés). Ou pour reprendre un article de l'auteur, son œuvre est devenue progressivement une croyance dont la valeur est telle que même ses détracteurs peuvent en tirer profit" (de Singly 1998).
} 
zależności: im szerszy krag czytelników B\&Co., tym skuteczniejsze działanie „zacierania śladów współpracy”.

Prawo odległości działawtensposób,iżim dalej od epicentrum (poza Francja), tym bardziej opisane tu praktyki wydaja się nieznane. Jest to oczywiste, jeżeli weźmiemy pod uwagę barierę językowa, ale także dostępność pewnych źródeł. Niemniej jednak największą przeszkodę w rozpowszechnieniu wiedzy na temat Bourdieu \& Co. upatruję w skłonności niektórych członków naszego środowiska do utrzymania mitu geniusza Samotnego Naukowca - romantycznej wizji Uczonego. Mam nadzieję, że dokonane tu analizy usunęły tę przeszkodę i w odmienny sposób będziemy postrzegać nie tylko działalność Bourdieu, ale także naszą własną produkcję naukową.

Przecież biorąc pod uwagę wkład wszystkich socjologów pracujących w zespole Bourdieu - począwszy od pierwszych badań w Algierii - nie będziemy zdziwieni tak wielką produktywnością tego licznego zespołu, w którym działali najbardziej płodni socjologowie francuscy. Spojrzymy w odmienny sposób na liczne publikacje Bourdieu (nieomal każdego roku nowa książka) i, czytając je na nowo i uważnie studiując tekst, odnajdziemy wkład jego współpracowników ${ }^{42}$.

Wtedy zadamy sobie pytanie - na czym polegał „geniusz” Bourdieu?

\section{/// Anatomia sukcesu}

Ponieważ uważam, że termin ,geniusz” określa bogaty zespół złożonych elementów i często nieokreślonych (lub trudnych do określenia) czynników, które współdziałają ze sobą w pewien specyficzny sposób - trudny do uchwycenia bez dogłębnej analizy - w kolejnej części niniejszego artykułu dokonam dalszej dekonstrukcji mitu geniusza, analizując sukces Bourdieu. W pierwszej części ukazałam kolektywny aspekt badanej kariery, w tej zajmę się anatomią sukcesu.

Anatomia oznacza rozcinanie czy też krojenie, dlatego postaram się dokonać - zgodnie $z$ naukowym znaczeniem tego terminu - nie tylko opisu każdej z osobna sfery badanego zjawiska (sukces w karierze Bourdieu), ale także wykazać relacje między jego poszczególnymi elementami.

\footnotetext{
${ }^{42}$ Nie miałam możliwości zrealizowania mojego zamiaru obliczenia „miesiąco-etatów” wszystkich współpracowników Bourdieu, którzy prowadzili badania w ramach wieloletniej działalności Centrum.
} 


\section{Bourdieu $=$ Pierre + Felix}

Opowiadając o zjawisku Bourdieu \& Co., nie sposób odmówić kluczowej roli w tym przedsięwzięciu - swoistej karierze multiple - postaci samego Bourdieu. Nie wgłębiając się w jego cechy osobowe (cytowani w tym artykule jego współpracownicy dokonali tego w wystarczający sposób), należy podkreślić, że miał kompetencje konieczne do jednoczenia i mobilizowania ludzi do wspólnych (powinnam napisać „,wspólnych”, tak się bowiem później często okazywało) przedsięwzięć. Jego charyzma i zdolności oratorskie sa powszechnie znane. Można powiedzieć, iż był ucieleśnieniem swoich dwóch imion. Pierwsze - Pierre, w języku francuskim oznacza skałę (lub kamień) - stanowiło niejako potwierdzenie jego wytrwałości w podtrzymywaniu swych racji, narzucaniu swemu otoczeniu (najpierw bliższemu, a później coraz szerszym kręgom) swej wizji świata, trwaniu przy swych paradygmatach i koherentnym wewnętrznie systemie teoretycznym, który miał zastąić wszelkie dotychczasowe paradygmaty. Był też tytanem pracy-żelazna, czy też kamienna, dyscyplina regulowała jego codzienne życie. O tym, że sukces należy do ludzi wytwałych i pracowitych, mówi się zbyt rzadko (aczkolwiek ostatni bestseller Malcolma Gladwella jest właśnie poświęcony pracowitości jako drodze do sukcesu; Gladwell 2008).

Drugie imię, którym nazywał go często Passeron (tak też był Bourdieu nazywany za czasów studenckich) brzmi Felix. Bourdieu także wydaje się w pełni odpowiadać etymologii tego imienia: szczęśliwy, mający szczęście w życiu i płodny. Kariera „francuskiego socjologa nr 1” jest właśnie przykładem specyficznego splatania się cech przypisanych jego imionom. Taka jest też pobieżna recepta na sukces w nauce: wytrwałość, konsekwencja, szczęście i płodność. Pierre + Felix!

Postarajmy się jednak w poprawny naukowo, a nie bazujący na odniesieniach literackich sposób poznać anatomię sukcesu. Aby tego dokonać, należy najpierw skupić się na tym etapie kariery Bourdieu, kiedy jeszcze jego sława nie produkowała samonapędzających się mechanizmów - co tak dobrze sam Pierre Felix przedstawił w analizie kapitału symbolicznego. Samonapędzająca się maszyna zadziałała dopiero po pierwszych publikacjach, a niewatpliwie przełomowym momentem w karierze Bourdieu Pierre'a, zanim stał się on twórcą marki Bourdieu \& Co., był sukces Les Héritiers. Książka ta, przełomowa nie tylko w karierze obu autorów, ale także w dziejach socjologii francuskiej, jest wspólnym dziełem tandemu Bourdieu/Passeron. 


\section{Opublikować znaczącą książkę i odnieść sukces wydawniczy!}

\section{Kulisy powstania i przyjęcia Les Héritiers}

Przed podjęciem analizy Les Héritiers przedstawię kontekst, w którym książka ta powstała, a także jej wpływ na socjologię francuska. Ponieważ w tym zbiorze interesuje nas sukces w nauce, dokładne poznanie kulis powstania książki, która odniosła niewątpliwy sukces czytelniczy, wydawniczy, finansowy, polityczny i naukowy, przejawiający się przeniknięciem do powszechnego użycia pewnych koncepcji - czyli analiza historii Les Héritiers ${ }^{43}$-stanowić będzie istotny element w analizie produkcji socjologicznych. Książka, o której mowa (podobnie jak jej kontynuacja La Reproduction, opublikowana w odmiennym kontekście „post 1968” - w 1970 r.), powstała na bazie badań ankietowych zrealizowanych wśród społeczności studenckiej, a także licznych obserwacji etnograficznych. Niezwykle istotny w zrozumieniu zjawiska, jakim było powstanie i następnie przyjęcie przez społeczność naukowa, polityków i resztę społeczeństwa tych dwóch pozycji, jest kontekst powstania dzieł. Nie poświęcając wiele miejsca Francji sprzed 1968 r., przytoczę tutaj opinię historyka francuskiej socjologii Jean-Michela Chapouliego, który podkreśla, że socjologia francuska po załamaniu powojennym odrodziła się nie na gruncie Durkheimowskim, ale dzięki działalności takich socjologów jak George Fridmann, Gabriel Le Bras, George Gurvitch i Jean Stotzel (Chapoulie 2005: 14). Ze względu na bardzo słabą pozycję instytucjonalną socjologii (nieliczne posady badaczy-socjologów w CNRS, brak wydziałów socjologii na uniwersytetach, nieliczne - nie więcej niż dziesięć w całej Francji - posady socjologów-dydaktyków pracujących na ogół na wydziałach filozofii, prawa czy geografii), badania naukowe w zakresie tej dziedziny były realizowane w ramach indywidualnych projektów nielicznych naukowców. Sytuacja się zmienia w momencie stworzenia licencjatu z socjologii (1958). Publikacja Les Héritiers w 1964 r. zmienia więc pozycję socjologii: niszowa nauka dociera do szerszych kręgów społeczeństwa dzięki książce traktującej o kulturze studenckiej. W tym czasie opublikowane zostają też inne pozycje, które przykuwają uwagę szerszej publiczności (Crozier 1963, 1965; Touraine 1967; Morin 1967). Niemniej jednak to Les Héritiers odnosi nieporównywalny sukces. Dlaczego?

\footnotetext{
${ }^{43}$ Książce tej poświęcono we Francji wiele uwagi, jako przełomowemu wydarzeniu w socjologii francuskiej, liczne konferencje, a także publikacje (Chapoulie i in. 2005; Masson 2008).
} 


\section{Kumulacja nowatorskich elementów}

Przypadek Les Héritiers potwierdza tezę, zgodnie z którą sukces w nauce dokonuje się dzięki pewnym odmiennościom. Po pierwsze, autorzy obrali tematykę, która dotychczas nie znajdowała się w centrum zainteresowań socjologów, główny nurt bowiem socjologii francuskiej lat 60. skupiony był na badaniach „,nowej klasy robotniczej”. Jednocześnie zauważa się pojawienie nowej warstwy społecznej, będącej nośnikiem rewolucyjnych idei - studentów ${ }^{44}$ (Chapoulie 2005: 15). Ale zainteresowanie kwestiami dotyczącymi młodych ludzi stanowiło w owych czasach domenę filmu (francuska nouvelle vague), a następnie mediów (Sohn 2005: 124-128). Mimo że autorzy podjęli ten „medialny” temat, to nie przyjęli powszechnej wówczas w dyskursie medialnym i intelektualnym postawy (Bourdieu, Passeron 1963). W przeciwieństwie do pewnych socjologów, ale także dziennikarzy (praca lewicowa i centrowa), którzy pisali o tendencji zanikania klas społecznych, zwłaszcza w zakresie praktyk kulturowych, Bourdieu i Passeron uważali, że istniejąca w przeszłości ,winda społeczna” przestała funkcjonować i dostęp do studiów wyższych, jak i praktyki kulturowe studentów, są klasowo zdeterminowane. Tak więc, śledząc kontekst i publikacje autorów powstajace w tym czasie, można stwierdzić z pewnością, że Les Héritiers zostali napisani w odpowiedzi na głosy oznajmiające koniec klasowości społeczeństwa francuskiego. Vivianne Isambert-Jamati (2005) zwraca uwagę na inny element kontekstu, a mianowicie wpływ eksplozji instytucjonalnej CNRS-u ${ }^{45}$, która dynamizowała środowisko socjologów w latach 60. Kolejnym czynnikiem były z pewnościa prace dotyczące szkolnictwa, realizowane $\mathrm{w}$ innych krajach (Prost 2005). Kontekst historyczny, a zwłaszcza działalność samorząqów studenckich i profesorskich, stanowią również istotny element pozytywnego przyjęcia wyników tego badania o środowisku studenckim. Dzieło odniosło we Francji sukces czytelniczy i do dzisiaj nie zdetronizowała go żadna inna publikacja socjologiczna.

Inne cechy pracy Bourdieu/Passerona sa godne podkreślenia: ich wysoki profesjonalizm w realizacji badania i wpływ etnologicznego zacięcia Bourdieu, występującego już w pracach dotyczących Algierii, a polegającego na przywiązywaniu wielkiego znaczenia do poznania percepcji badanego świata przez aktorów społecznych (Chapoulie 2005: 16). Istotną rolę w tym

\footnotetext{
${ }^{44}$ Termin student - etudiant - w języku francuskim nie jest zarezerwowany jedynie dla studentów wyższych uczelni i uniwersytetów, ale odnosi się także do niższych szczebli szkolnictwa - stąd też termin jeunesse obejmuje najczęściej młodzież w wieku od 15 do 25 lat. Na temat rozwoju kategorii jeunesse więcej w wyczerpującym artykule Sohn (2005).

${ }^{45}$ Odpowiednik PAN-u. Instytucja ta została mocno rozbudowana w końcu lat 60.
} 
nowatorskim jak na ówczesne czasy podejściu odegrało użycie w badaniu metody etnograficznej, a także inspiracja pracami socjologa brytyjskiego Basila Bernsteina.

Kolejną quasi „techniczną” innowację stanowi odmienne używanie referencji - jak sam Bourdieu mawial, ,nie do tego samego Marksa i nie do tego samego Webera się odwołujemy" (Chapoulie 2005: 16). Opublikowana w 1964 r. książka (krytykowana przez Raymonda Arona za eseizm ${ }^{46}$, co wskazuje na innowacyjne użycie języka naukowego) stanowi podstawę nowego ukierunkowania badań nad szkolnictwem. Została także wprowadzona innowacja typu technicznego, polegająca na prezentacji wyników z zastosowaniem graduacji zmiennych. Do najważniejszych jednak cech tej publikacji należy istota badania i zmiana podejścia do głównego problemu.

Chapoulie w swej analizie dzieła zwraca uwagę na rozbieżność między tytułem pracy sugerowanym w drugim członie - „Studenci i ich kultura” a tematyka pracy: „nierówności w dostępie do edukacji”" (Chapoulie 2005: 17). Tak więc podjęta tematyka stanowi obalenie podejścia obowiązującego od wielu lat w badaniach szkolnictwa $\mathrm{i}$ jest początkiem całego kierunku badań francuskiej socjologii edukacji. Przełom dokonany w tym dziele polega nie tyle na uwzględnieniu pochodzenia klasowego jako zmiennej determinującej dostęp do edukacji (podejście praktykowane przez INED), ile na potraktowaniu pochodzenia klasowego jako fenomenu, który należy poddać wyczerpującej analizie. Tak więc nierówności występują nie tylko w dostępie do edukacji, ale i w trakcie całego procesu edukacyjnego, ponieważ istotne jest doświadczenie rodzin (zdeterminowane klasowo), które wpływa na percepcję całego systemu kształcenia, determinując umiejętności poruszania się w instytucjonalnym świecie edukacji (ciekawym problemem poruszanym tutaj były orientacje profesjonalne - wybór szkół i kierunków kształcenia).

Ostatnim, niezmiernie ważnym elementem, który sprawił, że Les Héritiers stało się lekturą podstawową każdego francuskiego socjologa, jest wysoki poziom jakości zrealizowanych badań, uzyskany nie tylko dzięki pracy partnerów sprzężenia karier Bourdieu/Passeron, ale także dzięki wkładowi innych współpracowników, którzy uczestniczyli przy zbiorze i analizie danych. Są nimi statystycy, wypróbowani jeszcze w Algierii wspó1pracownicy Bourdieu: Claude Seibel i Françoise Evrard ${ }^{47}$.

\footnotetext{
${ }^{46}$ Termin „esej” jest użyty przez autorów w dedykacji na egzemplarzu książki ofiarowanej Fernandowi Braudelowi (zdeponowanym w bibliotece MSH w Paryżu; Chapoulie 2005: 28).

${ }^{47}$ Ich działalność także przyczyniła się do wysokiego poziomu realizacji badania statystycznego, do którego wprowadzono innowację, a mianowicie systematycznie zastosowano, w ślad za INSEE, w którym obaj wymienieni statystycy pracowali, kategoryzację społeczno-zawodowa (CSP - kategorię
} 


\section{Być we właściwym miejscu we właściwym momencie w doborowym towarzystwie}

Powyższe zdanie, które brzmi jak wyświechtana maksyma, ilustruje doskonale atuty, które Bourdieu potrafil wykorzystać, budując swą karierę socjologa. Bycie we właściwym miejscu oznacza nie tylko znajdowanie się we właściwej instytucji, ale także umiejętne wpisanie swej kariery w kontekst społeczny oraz otaczanie się takimi ludźmi, których praca umożliwi nam realizację kolejnych etapów kariery; współpraca z nimi sprawi, że jakość naszych prac stanie się znacznie wyższa niż efekty działania w pojedynkę.

\section{Noblesse par adoption - szlachectwo przez adopcję}

Bourdieu był jednym z ostatnich przykładów efektywnego działania szkoły republikańskiej Jula Ferry'ego. Doskonały uczeń w podstawówce zostaje zauważony w liceum i dzięki rekomendacji nauczyciela udaje się do Paryża, aby kontynuować naukę w École Normale Supérieure (ENS). Jest to klasyczna trajektoria dzieci z „niższych klas”, które wyróżniały się w szkole zapałem do nauki i dobrymi wynikami. Sławna ENS przy ulicy Ulm w Paryżu to francuska kuźnia elit naukowych ${ }^{48}$ - kształci się tam filozofów - i właśnie dzięki przygotowaniu otrzymanemu w tej instytucji Bourdieu zda bardzo poważany egzamin, zwany ,agregacja”, z dziedziny filozofii. Dzięki temu, że był tzw. normalien, wchodzi w kręgi elit uniwersyteckich i zdobywa to, co później nazwie kapitałem społecznym - liczne kontakty $z$ innymi normaliens, od których otrzyma pomoc i wsparcie w Algierii i po powrocie ${ }^{49}$. Właśnie Aron pomaga mu znaleźć pracę (normaliens są

\footnotetext{
socjoprofesjonalną, czyli pochodzenie respondenta bazujące na zawodzie ojca), używając jej jako podstawowej kategorii analitycznej.

${ }^{48}$ Kilka dodatkowych informacji umożliwi pełne zrozumienie tego, czym jest ENS - nawet w dzisiejszym kontekście. Aby być studentem ENS - normalien - należy zdać bardzo selektywny egzamin, do którego podchodzą studenci z licencjatem, rzadziej po drugim roku studiów na uniwersytecie. Ci, którzy przejdą sito egzaminacyjne, będa studiowali pod kierunkiem wybitnych profesorów, w małych grupach, mając świetne warunki mieszkaniowo-finansowe. Otrzymują pensję nauczycielska - około $1300 €$, status fonctionnaire, czyli pracownika państwowego, miejsce w domu akademickim (jednoosobowe pokoje), dostęp do wyśmienitych bibliotek, dobre warunki nauki: a więc wszystkie problemy organizacji życia codziennego (łącznie z gotowaniem - nawet stołówka ENS przypomina bar dla studentów tylko pod względem cen) są zniwelowane do minimum. Studenci mogą w pełni poświęcić się pogłębianiu wiedzy i przygotowywaniu do kolejnych egzaminów: magisterskiego, a następnie agregacji. Właściwie wszyscy uzyskują bez trudności posady asystenckie, które dzięki statusowi pracownika państwowego umożliwiają im utrzymanie się w trakcie doktoratu. Na ogół bez kłopotów wygrywają konkursy na posadę adiunkta - od momentu wstapienia w szeregi normaliens młodzi ludzie wkraczają na drogę kariery francuskich elit naukowo-dydaktycznych.

${ }^{49} \mathrm{Na}$ polecenie Clemence Ramnoux, profesorki filozofii greckiej, która była koleżanką Arona (z tej
} 
pracownikami państwowymi i mają nakazy pracy, aby spłacić studia i otrzymane stypendia), ofiarując podwójną posadę: asystenta na Sorbonie i sekretarza w CSE. Sorbona przed 1968 r. jest jeszcze TĄ Sorbona, po której ślady tylko zostały w wyniku decentralizacji lat ,post '68”. Instytucja jest prestiżowa i mentor wyśmienity - Bourdieu kontyuuje swą drogę kariery w jak najbardziej elitarnej wersji. Następnie wykłada w Lilles - na uniwersytecie usytuowanym w mieście robotniczym, o silnych lewicowych tradycjach i postępowych rozwiązaniach (w stosunku do konserwatywnej Sorbony). To właśnie w Lilles otwarto nowy kierunek - socjologię - i to właśnie w pociagu między Lilles a Paryżem Bourdieu wraz z innymi młodymi wykładowcami prowadzi zażarte dyskusje, przedstawiając swe poglądy. Praca na nowo utworzonych kierunkach nacechowana jest zawsze specyficzną dynamika, opartą na nowicjuszowskim entuzjazmie i wysokim zaangażowaniu ludzi, którzy, tworząc swą pracą to nowe miejsce, ponoszą pewne ryzyko (niebycia konwencjonalnym). Najczęściej znajdują się w takich miejscach młodzi wykładowcy, ludzie myślący inaczej, którzy, zachęceni ideą postępu, pragną w nim uczestniczyć. Ten mechanizm zdynamizowania jest widoczny w przypadku karier naukowców także dzisiaj (por. Wagner 2011).

Kolejne instytucje, w których działał Bourdieu, nie miały tego nowatorskiego aspektu, chociaż Centrum Socjologii Europejskiej działające w ramach EHESS (przedtem nazywanej École Pratique des Hautes Études EPHE) z pewnością było ewenementem ze względu na prace badawcze realizowane w ramach jego działalności i fakt, że ich zasięg przekraczał granice Francji - na owe czasy była to istotna innowacja. Samo EPHE było już od lat 50. prestiżową instytucja (miejsce działalności Szkoły Historycznej Les Annales), tak więc Bourdieu utrzymał tutaj swą elitarną pozycję, umacniając ją dzięki nominacji do Collège de France. Wraz z apartamentem służbowym przy placu Vendôme, przysługującym profesorom z tej najbardziej prestiżowej francuskiej instytucji naukowej - a więc symbolicznym potwierdzeniem pozycji dominującej na „polu akademickim” - Bourdieu osiagnął najwyższe szczeble hierarchii dostępne we francuskim świecie naukowym. Potwierdzeniem tej zawodowej drogi najwyższych lotów był złoty medal CNRS-u, przyznawany najwybitniejszym naukowcom francuskim. Można niewątpliwie stwierdzić, że Bourdieu przeszedł wszystkie etapy kariery, pracując $\mathrm{w}$ instytucjach najbardziej pożądanych dla realizacji swoistego parcours sans fautes.

samej promocji w ENS), Bourdieu skontaktował się z Aronem i został wkrótce jego asystentem na Sorbonie. Jak sam nasz bohater podkreśla, w tym fakcie „kolejny raz można zauważyć rolę, jaką odegrała École Normale w pozornych «przypadkach», które zbudowały moja karierę" (Bourdieu 2004: 48). 


\section{Umiejętność wykorzystywania sprzyjających wiatrów}

Na podstawie sukcesu wcześniej omawianej publikacji wskazałam, jak istotny dla realizacji kariery jest kontekst powstania i rozpowszechniania rezultatów prac naukowych. Wyjątkowe lata między wojną w Algierii a $1968 \mathrm{r}$. stworzyły specyficzne warunki do realizacji i przyjęcia przez dynamiczne społeczeństwo prac socjologicznych. Bourdieu doskonale potrafil dostosowywać swe zainteresowania naukowe do tego, czym pasjonowało się społeczeństwo. Podejmował tematy palące, aktualne, ale równocześnie stosował odmienną od dominujących tendencji perspektywę. Dzięki umiejętnościom mediacyjnym (do których powrócę) Bourdieu odniósł sukces $i$ to on narzucal własne wizje, które z czasem stały się dominującym we Francji paradygmatem. W takiej sytuacji trudno pozostawać krytycznym trudno być w opozycji do samego siebie. Ale sukces już został osiagnięty, a zasada Mertona opisująca fenomen samonapędzającego się sukcesu w nauce doskonale funkcjonowała. Nawet więc spóźnione publikowanie na modne tematy (Męska dominacja po ukazaniu się książki Judith Buttler) nie wpłynęło druzgocząco na twierdzę zbudowaną przez Bourdieu. Bourdieu \& Co. niewątpliwie było ,pewną” marką.

\section{Bourdieu \& Co.}

Dobieranie odpowiednich współpracowników jest jedną z najcenniejszych umiejętności osób, które zarządzaja praca zespołowa - a taki styl pracy w nauce uprawiał od samych początków swej działalności Bourdieu. Nie były to popularne już wtedy tandemy czy też sprzężenia karier, ale multiples - równoległe sprzężenia karier, realizowane z najlepszymi specjalistami w danej dziedzinie badań, zarówno jeżeli chodzi o tematykę (kultura kabilska i migracje - Sayad, szkolnictwo i kultura - Passeron, produkcja elit de Saint-Martin, kadry i inżynierowie - Boltanski, managerowie - Villette, artyści - Delsaut, fotografia - Chamboredon i Boltanski itd.), jak i specjalizację (statystycy, demografowie, etnografowie). Oczywiście umiejętne wykorzystanie tych niesłychanych ,zasobów ludzkich” czy też kapitału naukowego zależało od talentu organizacyjnego Bourdieu. Do pewnego stopnia jego przedsięwzięcie działało wyśmienicie. Praktyka zacierania współpracy była niesłychanie owocna z punktu widzenia kariery samego Bourdieu. Kumulacja pracy dziesiątek osób pod jednym nazwiskiem jest świetnym posunięciem marketingowym - o ileż łatwiej jest zapamiętać jedno nazwisko i kumulować kapitał reputacyjny na wielkim sukcesie „Bourdieu - Passeron, autorzy Les Héritiers". 
Bourdieu nie był pierwszym ani ostatnim, który uciekał się do takich praktyk. Każdy z nas może podać wiele przykładów tego typu działań ze swego otoczenia, a moje badania w środowisku naukowców pracujących w laboratoriach także obfitują w relacje o podobnych zjawiskach i liczne obserwacje dotyczące zacierania śladów współpracy potwierdzają w pełni dane uzyskane z wywiadów. Warto też wspomnieć, że w świecie artystów jest to praktyka stosowana od lat. Koncerty Vivaldiego nie są napisane jedynie przez niego (były powielane przez jego uczniów - mówi się, że on sam napisał jeden koncert, który jest powtórzony w setkach wersji). W Requiem Mozarta słychać frazy Mszy h-moll Bacha (w odnajdywaniu tego typu wpływów lubuja się muzykolodzy), a Schonberg także nie był ani pierwszym, ani jedynym kreatorem dodekafonii, ale dzięki umiejętności nagłaśniania swoich osiagnięć wpisał się do historii muzyki jako pierwszy i jedyny ${ }^{50}$. Mechanizmy, którym poświęciłam pierwszą część niniejszego artykułu, moga skutecznie przyczyniać się do umacniania kariery wybranej osoby. Rzadko dzieje się to za przyzwoleniem wszystkich uczestników wspólnych działań. Interesującym wyjątkiem może tutaj być fenomen szkoły matematycznej Bourbaki, która skupiała matematyków pod jednym (i to fikcyjnym) nazwiskiem (Altan 2003). Tym, co wyróżnia Bourdieu w stosowaniu tego typu praktyk, jest doprowadzenie ich do perfekcji i uzyskanie wysokiego stopnia efektywności: zdobyta międzynarodowa sława przy jednoczesnej nikłej wiedzy odbiorców o innych współautorach. Często można spotkać się z argumentem, że żaden z partnerów Bourdieu nie zrobił porównywalnej mu kariery (choć Boltanski i Wacquant, a także Passeron i inni należą wszak do znanych socjologów). W odpowiedzi na ten zarzut trzeba podkreślić, że nie pracowali oni w tak licznych zespołach - a nawet jeśli tak by było, to nie stosowali na szeroką skalę praktyk zacierania. Nie mieli zatem po prostu warunków do realizacji przedsięwzięć podobnych do Bourdieu \& Co. Na osiagnięcie sukcesu - jak widać po tej jeszcze nieukończonej liście - składa się wiele różnorodnych czynników; nie wszystkie są merytoryczne.

\section{Produkcja i post-produkcja:}

\section{kreatywność i umiejętność propagowania własnych dokonań}

Produkcja: stworzenie własnej „école de penser”

Wierni współpracownicy, którzy pod dyktando wyznaja podobne paradygmaty i przyczyniają się do rozpropagowania idei mistrza, są zalążkiem

\footnotetext{
${ }^{50}$ Informacje o Vivaldim i przykłady kompozytorskich zapożyczeń zawdzięczam licznym opowieściom mojego ojca - kompozytora - Juliusza Karcza, a za opowieść o Schonbergu dziękuję serdecznie kompozytorce Jagodzie Szmytce.
} 
i podstawa funkcjonowania tzw. szkoły, dawniej opatrywanej przymiotnikiem filozoficznej - w przypadku Bourdieu należy użyć określenia: socjologicznej. Podobne podejście metodologiczne, a także wyznawanie tych samych paradygmatów oraz konsekwentne stosowanie wspólnych narzędzi teoretycznych powoduje stworzenie jednolitej szkoły (nazwa szkoły sugeruje właśnie tę jednolitość). Działalność Bourdieu \& Co. jest właśnie przykładem szkoły socjologicznej - rzadkim przykładem, ponieważ nasza nauka nie obfituje w tego typu fenomeny. Dlaczego? Poniższy cytat z Passerona jest adekwatną odpowiedzią na to pytanie, a także dostarcza wyjaśnienia przyczyn konfliktu (czy też wskazuje na jeden z powodów sporu), który spowodował koniec działalności partnerów w niezwykle płodnym sprzężeniu Bourdieu/Passeron:

Od kiedy pamiętam, sama idea „szkoły” zawsze kłóciła się z moją koncepcją „wyobraźni socjologicznej”, którą Wright Mills przeciwstawiał bezsensowi badań prowadzonych na podstawie systemów „wielkich teoretyków” (jak Parsons). Również jest ona [wyobraźnia socjologiczna] przeciwstawna sterylnym działaniom „,biurokratów empirii” i przedsiębiorców uniwersyteckich, którzy organizowali i nadzorowali z wysokości swych lukratywnych pozycji jakże powtarzające się nudne i mało kreatywne surveys (w stylu American Soldier) (Passeron 2005: 54).

Szkoła zagwarantowała rozpowszechnianie teoretycznych paradygmatów i odegrała rolę bazy dla produkcji i reprodukcji pewnego typu badań, które stały się w krótkim czasie nie tylko rozpoznawalne w świecie francuskiej socjologii, ale zdominowały go w spektakularny sposób - na pewien okres zmuszając „opozycję” do podziemnych działań (Verdès-Leroux 1998).

\section{Produkcja: stworzenie własnej teorii - mediacyjny eklektyzm}

Sukcesem jest stworzenie własnej wizji świata i narzucenie go jak największej liczbie osób - początkowo specjalistom (socjologom), a następnie upowszechnienie go poza kręgami intelektualnymi. Bourdieu z pewnością operował pewnym systemem pojęć teoretycznych, które wzajemnie funkcjonowały w stworzonej przez niego przestrzeni koncepcyjnej. Czy potrafił narzucić ją innym? Wielogłosowość krytyk występujących wśród francuskich socjologów (chociażby Grignon, Passeron 1989; Grunberg, Scheisguth 1996; Verdès-Leroux 1998; de Singly 1998; Lahir 1998; Lacoste-Dujardin 1997, 1998-1999, 2007; Grignon 2002; Verdrager 2010) każe wattpić, czy sukces Bourdieu - niewatpliwie spektakularny w latach 80 . - jest trwałym zjawiskiem, tzn. czy teoria, która zdominowała socjologię 
francuską u schyłku XX w., była fenomenem tamtych czasów, czy też stała się jedną $z$ wielu propozycji teoretycznych występujących w socjologii: Natura teorii, które były opracowywane w CSE, zależała od tego, w jakim celu się jej używało (np. czy do analizy danych empirycznych). Zależała także od stopnia realizacji danych badań. Ankieta miała dawać teorii podporę, materiał [,materiał” jest tutaj odpowiednim terminem], lub przeciwnie, zależała od elementów, które umożliwiały zdecydowanie, która z konkurencyjnych interpetacji zwycięży. Zamiast zrobić selekcję, a następnie zebrać, bardziej lub mniej świadomie, zbieżne fakty mogące zilustrować i potwierdzić siatkę interpretacji, z którą wchodziliśmy w badanie (lub uwypuklić pozornie niepoddające się fakty, aby wykazać, że wbrew wszelkim oczekiwaniom one także moga być przedstawione w formie schematu, który się „miało w głowie”) zgodnie z tym, jak nami kierowała nasza kultura literacka i w szczególności nieomal wrodzona praktyka wyjaśniania tekstów, trzeba było poświęcić się specjalnie, bez chwili wytchnienia, wyszukiwaniu „faktów umykających kontroli”, które mogły potwierdzić nasze poczattkowe intuicyjne odczucia i w ten sposób stworzyć hipotezy, które miałyby być odrzucone. [...] Ten typ pseudoteorii, skazany z zasady na to, że zawsze ma się rację, jest dokładnie odwrotnościa, w swej realizacji i celowości, teorii naukowych, które chcieliśmy praktykować. Tego typu teorie znajduja wyznawców i spotykają się z entuzjastycznym przyjęciem dlatego, że pozostaja, podobnie jak dzieła literackie czy artystyczne, projekcją pewnego temperamentu na rzeczywistość, a rzeczywistość ulega rozpuszczeniu w przesadzonym skrajnym subiektywizmie. Poza tym, że tego typu sposoby teoretyzowania przenoszą socjologię w stronę wiedzy hermeneutycznej, konstytuującej się wokół osoby mistrza, który wskazuje jak myśleć, uniemożliwiaja one rozwój tych teorii w socjologii, które są dla tej dyscypliny pożądane. Taka teoria prowadzi do zmniejszenia, a raczej poświęcenia „kolejnych etapów pracy, które zmieniłyby następujące po sobie instytucje w systemy, i właśnie dzięki tym umykającym kontroli efektom do zbudowania konstrukcji bardziej czy mniej harmonijnej” (Mauss 1969: 296) (Grignon 2002: 203).

Przesłanie Grignona - ponad dwudziestoletniego współpracownika Bourdieu - jest jasne: teoria „socjologa nr 1” blokowała rozwój socjologii. Jeżeli przyjmiemy za prawdziwe stwierdzenie, że bazą dla postępu w nauce jest różnorodność, to można się zgodzić, iż ostatnie dwudziestolecie XX w. we Francji, w wyniku hegemonii Bourdieu \& Co., nie tworzyło sprzyjających warunków dla rozwoju socjogii na bazie odmiennych orientacji teoretycznych ${ }^{51}$. Podobne zarzuty stawia Passeron:

\footnotetext{
${ }^{51}$ Np. nawet w 2006 r. podczas obrony mojej pracy doktorskiej musiałam długo uzasadniać, dlaczego nie posługiwałam się teoria pól. Odniesienie się do teorii Bourdieu było w tym okresie quasi obowiązkowe - oznaczało ono posługiwanie się nia, a nie poddanie jej krytyce.
} 
w moich seminariach doktoranckich przestrzegałem słuchaczy przed „wielką teorią" socjologiczna, totalną i przefortyfikowaną, jaką się stała teoria Bourdieu. Jestem zwolennikiem myśli i nauczania, które prowadzą do popierania roli heurystycznej i statutu „normalnego” oraz „konkurencji” teoretycznych. Wskazuję na brak w większości nauk historycznych warunków do prowadzenia obserwacji, które zapewniają naukom eksperymentalnym płodność dominującego czy jedynego paradygmatu teoretycznego (Passeron 2005: 81).

Niemniej jednak, dzięki narzuceniu tej jedynej wizji teoretycznej, w pewnym momencie socjologia Bourdieu wyszła poza mury uniwersytetu. Spopularyzował on socjologię na tyle, że publikacje dawniej czytane tylko przez specjalistów dotarły do szerszego czytelnika, a pewne koncepcje upowszechnione przez Bourdieu przeniknęły nawet do codziennego języka. Dzięki temu upowszechnieniu można z pewnością stwierdzić, iż socjologia jako nauka skorzystała, przestała bowiem (przynajmniej we Francji) być ubogą siostrą filozofii - stając się jej młodszą siostrą.

\section{Produkcja: stworzenie własnego języka}

Aby opisać fenomen specyficznego języka, którym posługiwał się Bourdieu, posłużę się fragmentem przemyśleń osoby, która przez szesnaście lat była odpowiedzialna za wydawanie pisma Bourdieu i czuwała nad spójnością stylową i teoretyczną artykułów publikowanych w „Actes de la Recherches en Sciences Sociales" (ARSS).

Zarówno literatura i filozofia, jak i socjologia, którą uprawialiśmy, musiała być pisana w taki sposób, aby „wyodrębnić znaczenie” materiałów, które zebraliśmy: aby nadać im czy znaleźć dla nich jakiś sens, trzeba było opatrzyć je komentarzem. Porównanie Les Héritiers (1964) czy L'Amour de l'art (1966) z La Réproduction (1971) świadczy o rozwoju ambicji teoretycznych tych dzieł, które zajmuja szczyty w hierarchii Centrum i które były dla nas wzorami. Wartość uznana danego dzieła zależała od stopnia jego uczestnictwa w propagowaniu stylu stworzonego przez Bourdieu i Bourdieu/Passerona, stylu niepodrabialnego, ale godnego naśladowania, stylu Szkoły Centrum, dzięki któremu socjologia CSE przeciwstawiała się wszystkim innym produkcjom socjologicznym. Poprzez repetycje, które tworzyły pewne wybrane wyrażenia, niejako sygnały rozpoznawcze i potwierdzające nasze zgrupowanie, tego typu style należą do „drewnianego języka polityki” z powodu ich niejasności i poziomu komplikacji, przez zapożyczenia z greki czy łaciny nie mniej natarczywe, przez ciężkość i długość scholastyczną zdań (Bourdieu). To był język ezoteryczny, który wzbudzał quasi religijne poczucie dumy i satysfakcji u tych, którzy, wdrożeni w lekturę, czuli się 
jedynymi, którym dane było odkrycie sekretu. Jak każdy styl, któremu udało się narzucić swe wymogi innym, sens treści zależał od formy: miało się wrażenie, że prawdy, do których Bourdieu i Bourdieu/Passeron doszli, nie mogły być sformułowane w odmienny sposób. [...] Niestety, ten styl był nieodłączny od osób, które go stworzyły, i ponieważ był przeciwieństwem języka uniwersalnego - nie można się było go nauczyć. Można było jedynie usiłować go reprodukować przez mimetyzm (Grignon 2002: 202) ${ }^{52}$.

Rzeczywiście, osobom nieznającym języka francuskiego trudno jest przybliżyć specyfikę stylu, którym posługiwał się Bourdieu. Tłumaczenia angielskie i polskie stanowią pewną adaptację oryginału, umożliwiająca większą przejrzystość tekstu. Tłumacze dzielą półstronicowe zdania i sprawiaja, że czyta się te teksty o wiele ,łatwiej” niż w oryginale. Styl Bourdieu stał się także elementem symbolicznej dominacji - czytanie jego książek (z wyjątkiem pozycji poświęconej TV) stanowi atrybut „,paryskiego intelektualisty/intelektualistki”. Przyznanie się do nierozumienia tekstów francuskiego socjologa oznaczało w końcu XX w. wielkie braki w edukacji i mogło być przyczyną wykluczenia z pewnych kręgów studenckich. Dopiero w konfrontacji z publikacjami amerykańskich socjologów, u których przejrzystość narracji jest zaletą, a nie wadą, a komplikacje stylistyczne sa uważane za zbyteczny kamuflaż ukrywający często brak zawartości merytorycznej (zob. Becker 1986 - podręcznik redagowania tekstów naukowych), podniosły się liczne głosy krytyczne pod adresem tego specyficznego stylu. Tak jak w przypadku krytyki teorii, negatywne oceny stylu Bourdieu stały się głośne, gdy był on już na najwyższych szczeblach hierarchii akademickiej i zyskał sławę w Stanach Zjednoczonych. Najbardziej krytyczni wobec specyficznego stylu Bourdieu pozostają Francuzi: niektórzy z nich wręcz sięgaja po angielskie tłumaczenia, aby sprawniej uporać się z tekstem.

\section{Postprodukcja: stworzenie przestrzeni do propagowania swych idei}

Po 1968 roku Bourdieu zyskał zupełną swobodę decyzji (nie podlegając już Aronowi), objął całkowitą władzę nad Centrum Socjologii Edukacji i Kultury w EHESS, angażując się, jak nigdy przedtem, w badania i intensywne, i ekstensywne. Coraz bardziej ambitnemu pisaniu refleksywnemu (ecriture de reflexion) i wszystkim tym wyżej wymienionym przedsięwzięciom towarzyszyło zdobywanie wielkich instytucji wiedzy i kalkulowana precyzyjnie interwencja w świecie prasy i wydawnictw (Passeron 2005: 74).

\footnotetext{
${ }^{52} \mathrm{O}$ tym specyficznym języku i stylu pisania wspomina także Villette (w tym zbiorze).
} 


\section{$\mathrm{Z}$ marginesu do mainstreamu - „Actes de la Recherches en Sciences Sociales"}

W 1975 r. ukazuje się „Actes de la Recherches en Sciences Sociales” (ARSS) - pismo, które ma „im pokazać, do czego jesteśmy zdolni” (Grignon 2002: 2005). Oznacza to, że Centrum będzie rozpowszechniać i legitymować teorie, a także specyficzny język praktykowany przez socjologów działających w ramach CSE. Ponieważ w latach 70. Bourdieu nie ma jeszcze takiej władzy, jaką zdobył w późniejszym okresie, powstaje pomysł na własny periodyk. Ma to na celu zagwarantowanie sobie (Bourdieu \& Co.) przestrzeni do publikacji takich tekstów, które w innych miejscach były odrzucane. Tak więc z „opozycyjnego” pisma ARSS staje się w ciagu kilku lat jednym z najbardziej znanych socjologicznych periodyków w języku francuskim. Wspominany już uprzednio Grignon w następujący sposób opisuje kulisy działalności ARSS:

Fakt, że był to periodyk, zmuszał nas do publikowania, do preferowania takich pomysłów na badania, które mogły zostać opublikowane - i to szybko opublikowane. Z czasem nie mieliśmy już innych motywacji do realizowania badań poza tą jedną: konieczność publikowania. Rywalizacja na łamach pisma zmuszała nas do pisania, i to szybkiego. W rezultacie prowadziło to do przyśpieszania prac empirycznych, a nawet ich porzucania, do zaniechania produkcji statystyk na rzecz „ethno-minute” (pobieżnych badań typu etnograficznego ${ }^{53}$ ); zamiast poważnej ankiety terenowej robiono lekki wywiadzik i pobieżne ankiety. Wylansowanie i sukces ARSS zbiegły się z porzuceniem wielkich badań empirycznych. Waga, jaką przywiązywano do ilustracji, prowadziła jedynie do prezentowania „fragmentów rzeczywistości” i nagich dokumentów, które stanowiły materiał empiryczny. Wolność, która obraliśmy, dawała nam ułatwienia, które prowadziły do uprawiania socjologii dziennikarsko-literackiej, z którą chcieliśmy przecież zerwać. Danie sobie prawa i możliwości do wykazania pewnych rzeczy uwalniało nas od ich udowodnienia. Naszym sposobem i na naszym poziomie liczyliśmy na działanie fotografii i na zdjęcia wystarczająco uderzające, aby przekonały czytelnika i spowodowały, że uwierzy w naszą socjologiczną ewangelię. Ulegając tym ułatwieniom, zamykaliśmy się w kręgu mniejszym i bardziej nas ograniczającym, niż ten, z którego wyszliśmy. Zamiast dostosować się do reguł konwencjonalnych, ale zarazem generalnych standardów, od których tak bardzo chcieliśmy się uwolnić, musieliśmy być posłuszni normom lokalnym i specyficznym, które wcale nie były mniej arbitralne,

\footnotetext{
${ }^{53}$ Chodzi tutaj raczej o pseudoetnografię, ponieważ nie można realizować etnograficznego badania ani pobieżnie, ani „szybko”. Jest to sprzeczne z podstawowa zasadą tego typu pracy badawczej, polegajacej na długotrwałym zanurzeniu w badanej populacji (long-term immersion).
} 
a jednocześnie były o wiele bardziej tyrańskie. Pismo w sposób decydujący wpływało na stylizowanie, a w konsekwencji uniformizację, kierunku myślenia pracowników Centrum. Specyficzny sposób myślenia na zewnątrz ujawniał się w typowej formie, emblematycznej i natychmiast rozpoznawalnej, robiąc z formy (wewnątrz grupy i w bliskiej przestrzeni wokół niej) podstawowe kryterium oceny tekstów.

„Styl pisma” zależał od kombinacji niewielkiej liczby procedur prezentacji, obowiązkowej gry słów (trope) i szyboletów ${ }^{54}$. Wszystkie te elementy sprawiały, że był on łatwo rozpoznawalny, a zarazem łatwy do imitowania. Z pewnością z tych powodów późniejszy sukces ARSS przyczynił się do przyciagnięcia do Centrum (kiedy już skończył się okres początkowego aktywnego zaangażowania w przeżycie pisma) całego pokolenia naśladowców - osób, które powielały ten styl. Ich główne zadanie polegało na dokładnym zastosowaniu obowiązującej doktryny. Tworząc ARSS, Bourdieu wzmocnił opozycję między Centrum a resztą środowiska socjologicznego. Było dla nas oczywiste, że rezerwowaliśmy nasze publikacje dla ARSS; nawet nie myśleliśmy, aby zaproponować je innym pismom, a zwłaszcza „Revue française de sociologie”. Zreszta, było mało prawdopodobne, aby inne pisma zaakceptowały nasze teksty (Grignon 2002: 207).

Ten obszerny fragment stanowi ilustrację a posteriori byłego uczestnika zdarzeń, będącego w centrum aktywności ARSS. Pismo to z niszowego periodyka stało się jednym $z$ najbardziej znaczących we francuskiej socjologii. Odmienny format (A4), czerwona okładka, fotografie, notatki z badań terenowych, specyficzny język, o którym Grignon wspominał, stanowiły elementy wyróżniające ARSS od innych - bardziej konwencjonalnych - pism socjologicznych. Dzięki niemu badacze zatrudnieni w Centrum czy też sprzyjający działalności zespołu Bourdieu \& Co. - mogli publikować swe prace.

Członkowie CSEK wywalczyli wspólnymi siłami przestrzeń, w której pismo się ukazywało. W ich opowieściach przeplata się np. wątek typowego dla sprzedawców - „domokrążców” rozpowszechniania pisma: każdy z socjologów polecał je u księgarzy w okolicy swego miejsca zamieszkania. Pomysł stworzenia nowatorskiego i ,innego" pisma się powiódł. Mimo wielu zewnętrznych i wewnętrznych (pochodzących z CSEK) ataków na ortodoksyjne przestrzeganie stylistycznych i teoretycznych ram narzuconych przez Bourdieu, pismo do dziś kontynuuje swą działalność, pielęgnując spuściznę CSE/CSEK ${ }^{55}$.

\footnotetext{
${ }^{54}$ Z hebrajskiego - język rozpoznawalny, charakteryzujący daną grupę (żargon).

${ }^{55}$ Ostatni numer ARSS (03/2010) jest poświęcony w całości kwestii gustu muzycznego.
} 


\section{Od własnej kolekcji po własne wydawnictwo}

Istotnym elementem propagowania idei są publikacje książkowe. Bourdieu wcześnie w swej karierze został dyrektorem własnej kolekcji „Le sens commun" - już w 1964 r. w wydawnictwie Minuit. W trakcie 28 lat jej funkcjonowania ukazywały się nie tylko książki Bourdieu i członków jego zespołu, ale także publikacje amerykańskie (np. pierwsze tłumaczenia Goffmana). W 1992 r. Bourdieu zmienia wydawcę na Seuil i jego kolekcja „Liber” stanowi przedłużenie perspektywy obranej w Minuit. Prowadzenie własnej kolekcji gwarantowało doskonałą kontrolę nad działalnościa swej firmy (Bourdieu \& Co.) i rozpowszechnianie propagowanych idei nie tylko przez publikacje członków zespołu, ale także liczne tłumaczenia. $\mathrm{Na}$ rynku książek socjologicznych obie kolekcje stanowiły jedne z najbardziej rozpoznawalnych „marek” dorobku intelektualnego w naszej dziedzinie.

Ostatnim pomysłem wdrożonym przez Bourdieu było przeniesienie idei livre de poche (książka kieszonkowa, wydana w małym formacie i niewielkim kosztem - założeniem wydawcy było dotarcie do średnio uposażonego czytelnika, np. studentów, a atutem była pewnego rodzaju strona praktyczna - książki te są lekkie i niewielkie, praktyczne do czytania w środkach komunikacji miejskiej). W 1995 r. powołuje do życia wydawnictwo Raison d'agir, które publikuje książki nie tylko socjologiczne, ale także zaangażowane politycznie, głoszące krytykę neoliberalizmu. Szata graficzna (czerwony kolor, specyficzna czcionka) odwołuje się do ARSS; cena każdej książki (około stustronicowej) została ustalona na „mniej niż 50 franków francuskich" (około 8 euro). Wydawnictwo kontynuuje swą działalność do dzisiaj i podobnie jak uprzednio omówione przedsięwzięcia stanowi istotną część francuskiej przestrzeni wydawniczej w zakresie nauk społecznych.

Bourdieu, jak wiele osób realizujących kariery akademickie, doskonale znał warunki i zasady procesu wydawniczego. Aby zapewnić sobie i swojej grupie sprawne rozpowszechnianie wyników badań, stworzył platformę wydawniczą w formie kolekcji (a następnie nawet wydawnictwa) w celu umiejętnego zarządzania dysyminacja dokonanych odkryć. Można z cała pewnością stwierdzić, że nowa linia wydawnicza wytrzymała próbę lat i stanowi ważny i z pewnością rozpoznawalny element panoramy francuskiego świata wydawniczego.

O ile w tej formie uprawiania rozpowszechniania wiedzy trudno dopatrywać się nowatorstwa czy odrębności (poza wymienionymi detalami), o tyle działalność Bourdieu w mediach nie należała we Francji końca XX w. do typowych środków ekspresji wykorzystywanych przez osoby ze świata akademickiego. 


\section{Gra z mediami}

Ponieważ na ten temat pisano wiele i kwestia Bourdieu jako „najbardziej medialnego z niemedialnych" intelektualistów była we Francji wielokrotnie podejmowana, nie będę rozwijała tego zagadnienia, odsyłając czytelników do sugestywnej ksiażki Bourdieu Sur la Télévision, w której dokonuje on analizy funkcjonowania tego najważniejszego w XX w. środka przekazu, wykazując, w jaki sposób telewizja cenzurująco oddziaływuje na tych, którzy zdecydowali się na korzystanie z tego niezwykle opiniotwórczego medium. Bourdieu zaistniał w telewizji jako działacz - zaangażowany ( $\mathrm{z}$ inspiracji Foucaulta) w poparcie ruchu „Solidarności” - na początku lat 80., kontynuował swą działalność polityczną jako aktywista ruchów antyliberalnych w latach 90., a zwłaszcza w 1995 r. Był to okres długotrwałych strajków generalnych i paraliżu miast francuskich. Bourdieu jako zaangażowany intelektualista staje po stronie strajkujących, a następnie, u boku altermondialistów, opowiada się przeciwko negatywnym efektom globalizacji. Ta działalność, komentowana szeroko w mediach (z jego udziałem), powoduje, że Bourdieu zostaje pierwszym socjologiem, który odgrywa rolę intelektualisty publicznego na tak szeroką skalę. Rola ta dotychczas była zarezerwowana dla „mainstreamu nauki” - filozofów (Bernard-Henri Lévy). Obecność Bourdieu w mediach staje się obiektem krytyki ze strony społeczności akademickiej. On sam zyskuje status najbardziej znanego socjologa we Francji-Le sociologue. Tak więc dzięki telewizji jego sława wykracza daleko poza granice świata akademickiego. Bourdieu już nie tylko jest marka rozpoznawalną na uniwersytetach, ale „postacią medialną” - staje się uosobieniem francuskiego intelektualisty.

Obecność w mediach stanowi specyficzny (kontrowersyjny) element kariery naukowca. Jak pisał sam Bourdieu, uczestnictwo w tego typu działalności pociąga za sobą ryzyko nieoperacyjności, jak bowiem w ciagu trzech minut można przedstawić rezultaty dziesięciu lat pracy? Spłycenie informacji, jej wynaturzenie prowadzą do dezinformacji słuchaczy, a także do dyskredytacji pracy naukowca. Dlatego nie bez znaczenia jest negocjowanie $z$ mediami warunków uczestnictwa w tego typu działalności. O ile Bourdieu miał raczej negatywne doświadczenia z telewizja, o tyle przez pewien czas realizował audycje radiowe za pośrednictwem własnej rozgłośni, w której warunki prezentacji wyników prac lub propozycji teoretycznych badaczy były odmienne od tych, które cechuja programy telewizyjne o wysokiej oglądalności. Niemniej jednak to nie profesjonalne radio z quasi nieograniczonymi możliwościami czasowymi, ale właśnie skondensowne 
audycje telewizyjne prowadzone przez dziennikarzy-celebrytów zapewniły Bourdieu sławę i niespotykane dotąd we Francji w tym sektorze (nauki społeczne) rezultaty sprzedaży książek. Mimo licznych kontrowersji udział Bourdieu w mediach niewatpliwie umożliwił popularyzację jego publikacji naukowych na nieoczekiwaną skalę. Bycie czytanym i dyskutowanym jest podstawą sukcesu w karierze naukowca.

\section{Pozornie drugoplanowe elementy w konstrukcji sukcesu w karierze naukowca}

Hughes w analizie zawodów mówi o pobocznych cechach (auxiliary characteristics), które powinna mieć osoba realizująca określoną karierę (zawodowa) (Hughes 1971). Cechy te w pewnych przypadkach moga okazać się determinujące. Nie chodzi tutaj jedynie o pewne cechy personalne, ale także o wyróżnienie w danym przypadku kilku dodatkowych elementów kariery, które okazały się istotnymi determinantami spektakularnego wręcz rozwoju drogi zawodowej Bourdieu.

\section{Prekursorska europejskość}

Wbrew temu, co można przypuszczać, to Aron - a nie Bourdieu - stworzył Centrum Socjologii Europejskiej. Dzisiaj nie ma nic atrakcyjnego w terminie europejski, ale w momencie powstania tej instytucji (koniec lat 50.) Europa - jako zbiór państw tego regionu świata $-z$ punktu widzenia Francuzów (społeczeństwa państwa kolonialnego o silnym etnocentryzmie wyniesionym z kultu frankofonii i francuskiej kultury dominującej w XIX w.) nie była obiektem szczególnego zainteresowania. Z pewnością najistotniejszą rolę odegrała tutaj Fundacja Forda, która wsparła finansowo tę inicjatywę - jedną z wielu akcji amerykańskich w tym okresie (École Pratique des Hautes Études i biblioteka późniejszego Maison de Sciences de l'Homme działała prawie wyłącznie dzięki finansowaniu pochodzącemu z kasy federalnej USA ${ }^{56}$ ). Bourdieu jako sekretarz, a także dyrektor Centrum, najpierw nieoficjalny, a następnie (po 1968 r.) oficjalny, jak prawdziwy przedsiębiorca dowodzi silną (i coraz liczniejsza) grupa badaczy (na ogół młodych socjologów). Jednym z największych przedsięwzięć,

\footnotetext{
${ }^{56}$ Interesującym wydaje się więc fakt, iż Bourdieu latami pracował m.in. dzięki finansowaniu amerykańskich fundacji i rządu USA, które było (w konkurencji do francuskiej ekspansji kulturowej) amerykańską ekspansją kulturowo-lingwistyczną na szeroką europejską skalę; jak można łatwo stwierdzić, Amerykanie osiagnęli sukces w tej akcji: frankofonia stopniowo zanika, ustępując miejsca nie tylko amerykanizacji, ale i hispanizacji.
} 
zainicjowanym przez Raymond Moulin (współpracownica Arona), jest ankieta dotycząca publiczności muzeów - badanie porównawcze w skali europejskiej. Oczywiście z punktu widzenia XXI w. nie ma nic bardziej naturalnego. Jednakże na owe czasy było to przedsięwzięcie niesłychanie trudne zarówno z organizacyjnego, jak i politycznego (żelazna kurtyna) punktu widzenia. Opublikowane w książce L'Amour de l'Art badanie dotyczyło sześciu krajów, w tym Polski. W tym dziele Bourdieu dziękuje współpracownikom (współautorem jest Alain Darbel [et-i], jako drugi współautor [avec-z] występuje Dominique Schnapper; nazwisko tego ostatniego nie figuruje już na okładce, zgodnie z techniką zacierania udziału współpracowników). Warto tutaj wspomnieć, że niezwykle liczna ekipa, która pracowała przy realizacji tego badania, jest w dużej części - 54 osoby - wymieniona z imienia i nazwiska w podziękowaniach, $z$ dokładnym opisem wkładu pracy każdej z nich. Nawet jeżeli z punktu widzenia merytorycznego jest to praca mająca wiele niedociagnięć, to pomysł ankiety międzynarodowej został tutaj wykorzystany po raz pierwszy na podobną skalę. Niestety, wadą L'Amour de l'Art są poważne błędy metodologiczne: autorzy badania nie uwzględniają kontekstu oraz wyciagaja pochopne i błędne konkluzje ${ }^{57}$. Niemniej jednak wykorzystanie aspektu europejskiego w badaniach (nawet jeżeli był rezultatem amerykańskiej polityki zagranicznej) w tamtym okresie może być odczytane jako pozytywna decyzja sugerująca pewne nastawienie „prekursorskie”. Dzisiaj przedsięwzięcia tego typu stanowią większą część badań finansowanych w ramach polityki wspólnotowej. Tak więc można zrozumieć tych, którzy widzą w Bourdieu prekursora kolejnych edycji programów unijnych.

\section{Umiejętne przedstawianie porażek}

O porażce $\mathrm{w}$ nauce mówi się wiele $\mathrm{w}$ środowisku nauk przyrodniczych wśród badaczy eksperymentalnych ${ }^{58}$. Kiedy dziewięć doświadczeń na

\footnotetext{
${ }^{57}$ Posłużę się rodzimym przykładem, aby zilustrować błędy popełnione przy prowadzeniu tego przedsięwzięcia: badanie, przy którym wspólpracowali Polacy - porównanie muzeów polskich w latach 60 . do francuskiego Luwru i wyciaganie wniosków na temat praktyk kulturowych obu społeczeństw - wywołuje uśmiech na ustach tych, którzy pamiętają publiczność polskich muzeów w tych latach, a także tych, którzy znają zasoby obu miejsc. Oczywiście nie chodzi mi o krytykę takiego zamierzenia, ale o brak wyjaśnienia czytelnikom, jakie zbiory zawiera badana placówka, co w determinujący sposób wpływa na interpretację danych. Nie wspominam tutaj o praktykach typowych dla PRL-u, tzn. zwiedzaniu muzeów przez żołnierzy z jednostek wojskowych, dzieci ze szkół i innych przymusowych grupowych wizytach $\mathrm{w}$ tych instytucjach, które niesłusznie pominięto $\mathrm{w}$ analizach danych, kompletnie lekceważąc odniesienia do kontekstu.

${ }^{58}$ Interesujący artykuł na ten temat napisał Maciej Żylicz (2006).
} 
dziesięć kończy się fiaskiem - i jest to norma w wielu specjalnościach należy w trakcie socjalizacji jak najszybciej przyswoić umiejętność akceptacji takiej sytuacji jako specyfiki wykonywanej pracy (Delamont, Atkinson 2003). Słowo „porażka” jest używane w codziennym życiu przez badaczy laboratoryjnych. Potrafią oni mówić zarówno o swoich sukcesach, jak i niepowodzeniach - na przykład biolodzy, z którymi pracuję, prowadzą długie dyskusje na temat swych porażek badawczych.

Odmienną sytuację mamy w przypadku przedstawicieli nauk społecznych, czym bowiem jest dla nas porażka? Ostrą, czasem emanującą nieuzasadniona agresją anonimowa recenzją? Odmowa publikacji artykułu? Brakiem zaproszenia na konferencję? Czy też trudnościami ze znalezieniem wydawcy książki - „tej najważniejszej w naszej karierze” (czyli ostatnio napisanej i jeszcze niewydanej)? Odmową finansowania grantu? Brakiem finansowania stypendium wyjazdowego?

Rozmawiamy o swych bolączkach z przyjaciółmi, których spotykaja podobne zawody, ale porażki nie stanowia powszechnego tematu otwartych debat. Jak wykazałam w niniejszym artykule, Bourdieu doskonale potrafil znaleźć rozwiązanie w każdej z wyżej opisanych sytuacji, potencjalnie obarczonych ryzykiem porażki: odmowa publikacji artykułu - własne pismo, odmowa publikacji książki - własna kolekcja; odmowa grantu - kierownictwo Centrum (finanse były przyznawane w formie porównywalnej z naszymi „badaniami statutowymi”), brak zaproszenia na konferencje - organizacja własnej konferencji itd. Był samowystarczalny, a raczej potrafił stworzyć sobie swój własny świat, w którym on rozdawał karty. Uprzedzając możliwość porażek, tworzył sytuacje, które wieńczy sukces. Tak więc można byłoby przypuszczać, iż kariera Bourdieu to droga usłana sukcesami...

O porażkach się nie mówiło, przynajmniej publicznie. Wtajemniczeni wiedzieli natomiast, że Bourdieu nie miał doktoratu. Tuż przed wyjazdem do Algierii złożył projekt pracy doktorskiej pod tytułem: Structures temporelles de la vie affective (disposition pour "Thèse de doctorate d'état", Manuskript 1955). Pracował nad tekstem do 1957 r., ale nigdy go nie ukończył. Ponieważ był to projekt doktoratu $\mathrm{z}$ filozofii, a Bourdieu w Algierii stał się socjologiem, a ponadto po powrocie z Afryki spotkał Arona i został jego asystentem, w konsekwencji zmienił promotora i tematykę pracy. Kolejnym pomysłem na realizację doktoratu była teoria praktyki. Jak pisze sam Bourdieu w ,autobiografii”, zarzucony pomysł na doktorat zaowocował książką l'Esquisse - reszta materiału stanowiła podstawę Le Travail de l'Algérie i Déracinement. Bourdieu nie wspomina tutaj, że obie książki były napisane ze współpracownikami (Bourdieu 2004: 49). Natomiast 
zaniechanie doktoratu tłumaczy konfliktem z Aronem (który był zwolennikiem utrzymania Algierii francuskiej, a także prawicowym konserwatysta). Brak doktoratu nigdy nie był przeszkoda dla Bourdieu w dalszej karierze. Instytucjom, w których pracował, wystarczył jego dyplom nauczyciela dyplomowanego (agregation): zarówno EHESS, jak i Collège de France nie wymagaja (w przeciwieństwie do uniwersytetów) tytułu doktora.

\section{I ten łut szczęścia}

Nie będę rozważać kwestii szczęścia - czy też przypadku - w odkryciach naukowych, ponieważ temat ten był podejmowany dosyć często i dotyczy bardziej specjalistów nauk przyrodniczych niż humanistów (my długo analizujemy i później latami przekonujemy naszą społeczność, że nasza interpretacja zebranych danych jest najbliższa prawdzie - jak gdyby prawda obiektywnie mogła istnieć). W przypadku Bourdieu mówiono złośliwie o jego szczęściu: w końcu miał na imię Felix! A nazwisko... zaczynające się na B! B - czyli druga litera alfabetu! Ze spokojem mógł sobie pozwolić na współpracę i współautorstwo. Jego nazwisko zawsze widniało na pierwszym miejscu!!! Podobno właśnie dlatego Boltanski miał od samego początku kłopoty z „mistrzem” - przecież litera „”” znajduje się przed literą, „u”! Ten aspekt, pozornie bez znaczenia, przyczynił się także do tego, że nazwisko „Bourdieu” przy licznych kooperacjach stało się szybko szyldem maskującym pracę wielu dziesiątków socjologów - a więc Bourdieu \& Co.!

\section{/// Konkluzja nr 1: Bourdieu = kariera uczonego czy biznesmena?}

Z powyższej analizy, która nie pretenduje do przymiotnika „wyczerpująca”, wyłania się obraz niesłychanie dynamicznego i przedsiębiorczego człowieka. Działania skupione pod szyldem jego nazwiska są tak różnorodne i trwałe w czasie, że nasuwa się tutaj porównanie z ludźmi biznesu - aktywnymi wizjonerami. Ludzie odnoszący sukces w biznesie potrafia wykorzystać kontekst i sprowokować specyficzną konwergencję czynników, które dynamizuja ich kariery (Villette, Villermont 2009). Bourdieu dzięki „elastyczności rynkowej” (zmiana tematyki i podejmowanie aktualnych debat) potrafil sprostać potrzebom tego rynku (szeroki zasięg publikacji) i przez sprawne dobieranie pracowników, a następnie zarządzanie „kapitałem ludzkim” (umiejętny dobór najlepszych specjalistów w danej dziedzinie i efektywna organizacja pracy) i skuteczny management (w jego przypadku skuteczny, aczkolwiek krytykowany za feudalizm i despotyzm) produkował dobra, na które było zapotrzebowanie („modne” tematy: 
edukacja, świat akademicki, telewizja czy „męska dominacja”). Jeśli chodzi o innowacyjność i kreatywność, to - zgodnie z tezą Villette’a i Villermot (2009) - w przypadku wielkich biznesmenów jest to raczej umiejętne reklamowanie pewnych drobnych innowacji, niż podejmowanie prawdziwego ryzyka, jakie niesie produkcja rewolucyjnych wynalazków. W przypadku Bourdieu można dopatrzyć się analogii także tutaj: jego koncepcje sa według wielu socjologów odnowiona i uatrakcyjniona wersja klasyków socjologii: Marksa, Webera, Verblena, Eliasa, Durkheima (Verdès-Leroux 1998; Verdrager 2010). Tak więc przytoczone argumenty pozwalają nam stwierdzić, że kariera Bourdieu odpowiada raczej charakterystyce drogi zawodowej biznesmenów niż powszechnemu modelowi karier uczonych.

\section{„Art is I; Science is We” (Claude Bernard, cyt. za: Shapin 2008)}

Przywołując jednak inną cechę, która „zdominowała” wszelkie aspekty powyższej analizy - a mianowicie kumulację osiagnięć licznego zespołu badaczy pod jednym szyldem, eksponowanie postaci Bourdieu w świecie akademii, a także poza nim, mediatyzacjej jego osoby, a nawet odgrywanie roli celebryty - nasuwa się porównanie z procesem realizacji karier w środowiskach artystycznych ${ }^{59}$. Wspominaliśmy już o Vivaldim, ale są też inni: Stradivarius ${ }^{60}$, kompozytorzy, lutnicy, malarze - rzesze ludzi pracuja pod szyldem wielkich nazwisk. Podstawą tego funkcjonowania było stworzenie własnej szkoły artystycznej, rozpoznawalnej na podstawie specyficznego środka ekspresji - u Bourdieu był nim styl pisania. Wynajdowanie własnego języka jest kluczowym elementem konstrukcji stylu w sztukach - stylu, który ma być zindywidualizowany (regime de singularite - Heinich 2000) i jest następnie kopiowany (bardziej lub mniej udolnie). Podobnie dzieje się z opracowywaną formą i przesłaniami teoretycznymi.

Kolejnymi aspektami funkcjonowania szkół artystycznych jest organizacja pracy według modelu mistrz - uczniowie. Feudalne relacje tam panujące mają być podstawą socjalizacji w tych środowiskach (Wagner 2006). Nie ma tutaj miejsca na partnerskie stosunki, które powinny gwarantować

\footnotetext{
${ }^{59}$ Przestrzeń konceptualna dzieląca kariery w biznesie i kariery artystyczne w ostatnich latach znacznie się zmniejsza. Biorąc pod uwagę idee „,nowego ducha kapitalizmu” Boltanskiego i Chiapello (2006), można zauważyć, że większość cech wymaganych od nowoczesnych biznesmenów i menedżerów (por. podręczniki managementu) pokrywa się z cechami przypisywanymi artystom (kreatywność, mobilność, działanie oparte na sieciach współpracy, szukanie nowych zindywidualizowanych rozwiązań). Tak więc oczekiwania wobec tych kategorii nie są wcale tak odmienne, jak zwykło się postrzegać.

${ }^{60}$ Pokolenia lutników pracowały na sukces i legendę skrzypiec Stradivariusa. Nie tylko członkowie rodziny, ale także uczniowie - czeladnicy.
} 
jakość prowadzenia badań naukowych. Sztywne relacje hierarchiczne natomiast uniemożliwiaja proces przeprowadzania analiz naukowych w grupie (Wagner 2010). Baza postępu w nauce jest bowiem powaţpiewanie, sceptycyzm i kontestacja - występowanie tych elementów w zespole Bourdieu było niemożliwe.

Tak więc praca w CSEK znacznie bardziej przypominała funkcjonowanie szkoły artystycznej niż laboratorium naukowego. W szkole wierzy się w talent mistrza, w laboratorium szuka się luk i błędów w swojej i cudzej pracy. Bourdieu narzucał własną teorię, a odstępstwa od przyjętych dogmatów były tępione - dbał o „czystość” swej szkoły. W CSEK trzeba było wyznawać teorię Bourdieu - zgodnie z wszechobecnym prawem dominacji.

$\mathrm{Na}$ pytanie, czy kariera Bourdieu była odpowiednikiem kariery uczonego, czy raczej biznesmena, odpowiem... artysty! Być może dlatego jego twórczość wzbudza po dziś dzień emocje...

\section{/// Konkluzja nr 2: Sprzężenie karier drogą do sukcesu w nauce - ale czyjego?}

W pierwszej części tego artykułu dokonałam dekonstrukcji mitu geniusza w nauce, tak więc proces ten zakończę propozycją konstrukcji definicji geniusza. Jest to osoba odnosząca wybitny (większy niż osoby z otoczenia) sukces w danej działalności. Cechuje ją specyficzne połączenie licznych kompetencji i umiejętności, wśród nich umiejętność realizowania sprzężenia $z$ odpowiednimi osobami, których kompetencje są nieodzowne do realizacji określonych zadań (zastapienie własnych brakujących kompetencji tymi, które mają współpracownicy). W sprzyjających warunkach kontekstualnych (nowa instytucja, trend $\mathrm{w}$ danej dziedzinie, sytuacja polityczno-historyczno-ekonomiczna) wszystkie wymienione wyżej elementy zbiegają się, tworząc doskonałą podstawę do realizacji pewnych zamierzeń. Wytrwałość czy nawet determinacja są konieczne w realizacji celu. Należy także szczególną troską otoczyć etap komunikacyjny, czyli rozpropagowanie informacji na temat własnych (wspólnych) dokonań. O sukcesie wybitnej osoby można będzie mówić wtedy, gdy o jej dokonaniach dowie się otoczenie.

W jaki sposób osiąga się sukces w nauce?

$\mathrm{Na}$ sukces składa się odpowiednia strategia realizacji karier, dostosowanie do wymogów merytorycznych obowiązujących w akademii w danym momencie (np. dzisiaj Bourdieu musiałby być mobilny, przynajmniej na pierwszym etapie swej kariery; doświadczenie algierskie nie byłoby wystarczające - musiałby, jak Latour, mieć za sobą bagaż post-doka w USA, jego krótkie pobyty w Princeton byłyby niezadowalające). 
Bourdieu był niewątpliwie pod wieloma względami naukowcem swoich czasów: w naukach socjologicznych był prekursorem ekstremalnej realizacji strategii kumulacji: cała spuścizna pod jedną firmą - jedna marka. Umiejętnie potrafil wykorzystać szeroko rozpowszechnione w środowisku, typowe dla jego czasów przeświadczenie o wybitności jednostek. Eksploatował też znakomicie specyficzne dla tego okresu postrzeganie wiedzy, która zastapiła religię:

Wiara w to, że nauka potrafi udzielić odpowiedzi na wszelkie pytania [...] jest tak szeroko rozpowszechniona, że nauka przejęła funkcję społeczna, która oryginalnie była pełniona przez religię: funkcja ta polegała na zapewnieniu ostatecznego poczucia bezpieczeństwa. Tak więc wiara w naukę zastapiła, w szerokiej mierze, wiarę w Boga [...] (Reichenbach w: Shapin 2008: $31{ }^{61}$ ).

Przypadek Bourdieu stanowi doskonałą ilustrację zderzenia dwóch światów: starego, w którym uczony pracował samodzielnie - świata, w który wierzymy i według którego oceniamy $-\mathrm{z}$ nowym, w którym działamy. Nowy świat to praca w coraz liczniejszym zespole. Samotny naukowiec staje się rzadkim okazem. Jest to nasza środowiskowa „odpowiedź ewolucyjna" - nasza adaptacja do nowych warunków. Jeden człowiek nie jest w stanie spełnić aktualnych wymogów stawianych naukowcom w takim stopniu, aby na każdym etapie prac osiagać wyśmienite rezultaty. Badacz nie może prowadzić prac empirycznych, analizować, redagować, publikować, głosić teorii, kierować grupa, organizować podróży zawodowych, pisać grantów i zasiadać w komisjach, a zarazem intensywnie publikować w rytmie Pierre’a Bourdieu czy chociażby w tempie wymaganym przez władze - które dokonują ewaluacji naszych prac - będąc jednocześnie nauczycielem akademickim. A przecież to nasze publikacje przyczyniają się do zajęcia takiego, a nie innego miejsca w światowym rankingu uniwersyteckim. Jesteśmy zmuszeni przez taki system zorganizować nasza pracę w zespołach, aby nie tylko sprostać tym zadaniom, ale doprowadzić do publikacji wyników naszych badań i do ich popularyzacji w najbliższym środowisku, a także w szerszym gronie odbiorców. Wszak to właśnie przekonanie do naszych koncepcji, do naszych wizji świata powstałych w trakcie interpretacji wyników generowanych w naszych badaniach jest celem naszych działań. Sukces $\mathrm{w}$ nauce niekoniecznie wiąże się $\mathrm{z}$ transferem wyników badań do szerokiego odbiorcy, ale z pewnością z szerokim ich wykorzystaniem przez grono specjalistów (wzajemne dyskutowanie, cytowanie).

\footnotetext{
${ }^{61}$ The belief that the science has the answer to all questions [...] is so widely spead that science has taken over a social function which originally was satisfied by religion: the function of offering ultimate security. The belief in science has replace, in learge measure, the belief in God [...].
} 
Powszechna akceptacja takiego modelu wydaje mi się konieczna w dzisiejszych czasach. Nie chodzi tutaj o ortodoksyjne wyznawanie jednego typu działania - „tylko praca w zespole ma sens”. Ważne jest zróżnicowanie stylów organizacji pracy w nauce - zgodnie z wymaganiami danej dyscypliny, specyfiką projektu czy też temperamentem badacza. Różnorodność postępowania zwiększa szanse na urozmaicenie badań. Wszelkie typy organizacji są możliwe: od samotnego badacza do licznych grup, a nawet zespołów wielonarodowych, funkcjonujących w podgrupach - jak często dzieje się w wyniku między innymi specjalnych dotacji na projekty międzynarodowe, finansowane przez Komisję Europejską. Należy pamiętać o tych zróżnicowaniach w momencie oceny czy ewaluacji pracy naukowca $\mathrm{X}$.

Czym jest praca w nauce?

O ile sukcesem badacza jest dołożenie cegiełki do wspólnego dzieła zwanego postępem w nauce, to z punktu widzenia całości przedsięwzięcia nie jest ważne, czy dokładana cegiełka będzie efektem pracy jednej osoby czy całego zespołu - oby tylko przyczyniła się do rozbudowy czy ulepszenia, obalenia dotychczasowych przekonań lub przełomu w istniejącym stanie wiedzy (Kuhn 2001; Rabinov 1996).

Taką cegiełka jest też analiza naszych wewnątrzśrodowiskowych mitów. Rolą socjologa jest przecież niewątpliwie dekonstrukcja mitu - a więc także dekontrukcja mitu geniusza naukowca. Malcolm Gladwell w swym ostatnim bestsellerze napisal, ile godzin potrzeba na „stanie się” wyczynowym sportowcem, świetnym artysta, wyśmienitym specjalista - tym, kogo określa się mianem ,geniusza” (Gladwell 2008). Setki tysięcy godzin, zespoły ludzi pracujących nad stworzeniem wybitnych jednostek (zob. pracę socjologiczną zbieżną z tą perspektywą na temat skrzypków-wirtuozów - Wagner 2006). Nieskończona liczba godzin, ale także niezliczona liczba współpracowników, a raczej niezliczona ilość karier - można byłoby obliczyć sumę etatów, które wchodziły w skład prac sygnowanych „Bourdieu”.

Wybrany przypadek w ekstremalny sposób ujawnił mechanizm działający pozornie nienagannie (odmiennego zdania są ci współpracownicy, którzy zdecydowali się na zabranie głosu). Bourdieu - twórca i prezes korporacji, która pracowała na jedną markę Bourdieu (bez Co.) - sprytnie posługuje się mitem romantycznego uczonego, aby ukryć armię „,pracowników nauki”, których wkład w to jednoautorskie dzieło jest niezaprzeczalny. Od nas samych zależy, czy damy się uwieść tej romantycznej wizji, czy też obudzimy w sobie socjologa i przyjmiemy zaproponowaną wyżej dekonstrukcję tej legendy, czy będziemy uczestniczyli w budowaniu i utrzymywaniu tej mitologii w naszym środowisku, czy też, zgodnie z obecną organizacja pracy 
w nauce, będziemy potrafili umiejętnie i transparentnie budować nasze trajektorie zawodowe, wykorzystując inspirujące sprzężenia karier.

A sukces w nauce?

Biorąc pod uwage podział pracy i różnorodność organizacji pracy w nauce, dostrzeżemy, że jedni z nas pracują w licznym zespole, a inni podążaja sami - starając się, każdy na swój sposób, sprostać wytyczonym przez siebie wyzwaniom. Bourdieu był prekursorem pewnego rodzaju typu kariery w nauce - raczej artysty $z$ silnie zarysowanymi cechami celebryty i mistrza tworzącego swą szkołę („swój dwór”, jak mawiali jego współpracownicy). Ale sukces, który odniósł, jest jednocześnie zaprzeczeniem jego własnej teorii, którą narzucal innym. Jego kariera jest zaprzeczeniem tego, że dominacja klas, o której tyle pisał, determinuje drogę uczonego. On sam z dominowanego stał się dominującym, na przekór swemu urodzeniu ${ }^{62}$. Udowodnił całym swym życiem, że są takie przypadki, w których, dzięki wielu umiejętnościom, ciężkiej pracy i sprzyjającym warunkom, pochodzenie klasowe nie musi determinować życia człowieka. Jego wizja świata była niespójna z jego własnym życiem... Jego sukces był więc zarazem wielką porażką jego teorii...

Ale sukces Bourdieu był nie tylko jego własnościa - tak jak większość sukcesów odniesionych w świecie nauki, nie ma tylko jednego rodzica.

Niestety - lub na szczęście - nie jesteśmy artystami - zostawmy im indywidualną realizację wielkich dzieł. My próbujemy zrozumieć świat i dzięki pomocy innych (żywych ludzi lub dokonań przeszłych pokoleń) staramy się pogłębić (czy rozszerzyć) to, co dotychczas zostało zrobione. Każdy z nas realizuje swój wkład w naukę na własny sposób - solo, w duecie lub orkiestrze. Każdy sposób jest dobry, jeżeli przyczyniamy się do zrozumienia rzeczywistości, która nas otacza. Nawet ci, którzy pozornie nie odnoszą sukcesu, których droga, obrana w tym labiryncie, kończy się ślepa ścianą- swoją porażką wskazują drogę innym ${ }^{63}$. Tym, którzy znajdą dalsze przejścia w labiryncie, którym jest nauka. A praca dla nauki - to już jest sukces!

\footnotetext{
${ }^{62}$ Ponieważ w pokoleniu Bourdieu można było znacznie częściej niż po 1960 r. odnotować przypadki dobrego funkcjonowania ,windy społecznej”, a przed II wojną światową tego typu trajektorie były bardzo powszechne, to z pewnością nie można tutaj, w celu obrony teorii dominacji, zastosować argumentu „miracule”, czyli ocalonego - wyjątku potwierdzającego regułę. Liczba przypadków świadczących o możliwości zmiany determinacji klasowej, czyli zmiany swej pozycji w społeczeństwie (nawet francuskim), jest tak znaczna, iż rzeczownik miracle oznaczający cud nie może tutaj znaleźć zastosowania. Cud bowiem nie zdarza się codziennie.

${ }^{63} \mathrm{~W}$ niektórych naukach eksperymentalnych istnieją pisma (internetowe) poświęcone nieudanym eksperymentom lub nietrafionym pomysłom. Studiując te porażki, kolejni badacze pogłębiają swą wiedzę i, nie popełniając tych samych błędów, oszczędzają czas, który przeznaczają na dalsze pogłębienie tajników swej dyscypliny. Tak więc każdy wkład pracy w nauce jest cenny i potrzebny.
} 


\section{/// Podziękowania}

Jak każda praca, tak $i$ ten artykut nie powstałby bez. licznych rozmón $i$ wymian zdań, za które serdecznie dzięeuje: dr hab. Matgorzacie Jacyno, mgr Sylwii Urbańskiej, Philippe'owi Saffrayowi i Marcinowi Serafinowi. Wiele zawdzieczam także wypowiedziom Jean-Michela Chapouliego i Michela Villette'a. Nie oznacza to, iż. wssystkie wyżej wymienione osoby zgodzityby sie z analiza przeprowadzona w powyżsym tekśscie, za który ponosze wy taczna odpowiedzialność.

Bibliografia:

/// Aczel, Amir D. 2006. The Artist and The Mathematician. The Story of Nicolas Bourbaki, The Genious Matematician who never existed. Tunder's Mouth Press, Avalon Publishing Group, Inc.

/// Becker, Howard S. 1970. Sociological Work, Method and Substance. Chicago: Aldine.

/// Becker, Howard S. 1986. Writing for Social Scientists. Chicago: University of Chicago Press.

/// Becker, Howard S., Strauss, Anselm L. 1956. Careers, Personality, and adultsocialisation. „The American Journal of Sociology”, vol. LXII, nr 3.

/// Boltanski, Luc. 2003. Usages faibles, usages forts de l'habitus. W: Travailler avec Bourdieu. Paris: Flammarion, s. 153-161.

/// Boltanski, Luc, Chiapello, Eve. 2005. The New Spirit of Capitalism. London-New York: Verso.

/// Bourdieu, Pierre. 1989. La Noblesse d'État. Grandes Ecoles et esprit de corps. Paris: Minuit.

/// Bourdieu, Pierre. 1998. Pour Abdelmalek Sayad. Hommage prononcé à l'Insti-tut du monde arabe, le 2 avril 1998, à l'occasion d'une réunion en la mémoire d'Abdelmalek Sayad. „Publié dans la revue Annuaire de l'Afrique du Nord”, vol. XXXVII.

/// Bourdieu, Pierre. 2004. Esquisse pour une auto-analyse. Paris: Raisons d'agir, col. Cours et Travaux.

/// Bourdieu, Pierre, Darbel, Alain, Rivet, Jean-Paul, Seibel, Claude. 1963. Travail et travailleurs en Algérie. Paris-Den Haag: Mouton.

/// Bourdieu, Pierre, Darbel, Alain, Schnapper, Dominique. 1969. L'amour de l'art. Les musées d'art européens et leur public. Paris: Minuit.

/// Bourdieu, Pierre, Passeron, Jean-Claude. 1963. Sociologues des mythologies et mythologies des sociologues. „Temps Modernes”, nr 221, s. 998-1021. 
/// Bourdieu, Pierre, Passeron, Jean-Claude, Chamboredon, Jean-Claude. 1968. Le métier de sociologue. Paris: Mouton.

/// Castel, Robert. 2005. Pierre Bourdieu et la dureté du monde. W: Travailler avec Bourdieu. Paris: Flammarion, s. 347-355.

/// Chaib, Sabah. 2000. Abdelmalek Sayad, un noble, un juste et un généreux. W: H. Bresc, C. Veauvy (ed.). Les mutations d'identité en Méditerranée. Paris: Bouchene.

/// Chapoulie, Jean-Michel, Kourchid, Olivier, Robert, Jean-Louis, Sohn, Anne-Marie (ed.). 2005. Sociologues et Sociologies. La France des années 60. Paris: L'Harmattan, Logiques Sociales.

/// Delamont, Sara, Atkinson, Paul. 2001. Doctoring Uncertainty: Mastering Craft Knowledge. „Social Studies of Science”, nr 31(1), s. 87-107.

/// Dortier, Jean-François. 2002. Les idées pures n'existent pas. „Sciences Humaines", numéro spécial.

/// Fridman, Robert. 2001. The Politics of Excellence. Bebind the Nobel Prize in Science. New York: Times Books.

/// Gladwell, Malcolm. 2008. Outtiers. The Story of Success. New York: Back Bay Books.

/// Gouirir, Malika. 2007. P. Bourdieu et A. Sayad: une rencontre intellectuelle. „La revue de l'association culturelle berbére", nr 54-55, s. 17-20.

/// Grignon, Claude. 2002. Commentpeut-on être sociologue? „Revue Européenne de sciences sociales", XL, nr 123, s. 181-225.

/// Grignon, Claude, Passeron, Jean-Claude. 1989. Le Savant et le Populaire. Miserabilisme et populisme en sociologie et en litterature. Paris: Gallimard-SeuilHautes Etudes.

/// Grunberg, Gerard, Scheisguth, Etienne. 1996. Bourdieu et la misere: une approche reductionniste. „Revue Francaise de science politique”, vol. 46, nr 1, s. $134-155$.

/// Hanifan, Lyda J. 1916. The Rural School Community Center, „Annals of the American Academy of Political and Social Science", nr 67, s. 130-138.

/// Heinich, Nathalie. 1999. L'épreuve de la grandeur. Prix littéraires et reconnaissance. Paris: La Découverte.

/// Heinich, Nathalie. 2000. Etre écrivain. Création et identité. Paris: La Découverte.

/// Hermanowicz, Joseph. 1998. The Stars are not Enough. Scientists - Their Passions and Professions. Chicago: The University of Chicago Press.

/// Hughes, Everett H. 1958. Men and Their Work. Glencoe: The Free Press. 
/// Hughes, Everett H. 1996. Le regard sociologique. Paris: EHESS (wyd. oryg.: The Sociological Eye: Selected Papers. Chicago: Aldine Atherton, 1971).

/// Isambert-Jamati, Vivianne. 2005. Les Héritiers et la sociologie de l'éducation des années soixante: un témoignage. W: Chapoulie, Jean-Michel, Kourchid, Olivier, Robert, Jean-Louis, Sohn, Anne-Marie (ed.). Sociologues et Sociologies. La France des années 60. Paris: L'Harmattan, 2005, s. 79-86, Logiques Sociales.

/// Kuhn, Thomas S. 2001. Struktura rewolucji naukonych. Warszawa: Fundacja Aletheia.

/// Lacoste-Dujardin, Camille. 1997. Operation 'Oiseau bleu'. Des Kabyles, des ethnologues et la guerre d'Algerie. Paris: La Decouverte.

/// Lacoste-Dujardin, Camille. 1998-1999. L'offense faite aux Kabyles. „Actualites et cultures berberes”, nr 27-28, s. 38-43.

/// Lacoste-Dujardin, Camille. 2007. Retour sur Bourdieu. W: Actualites et culture berberes de Kabylie. Paris: La Decouverte.

/// Lahir, Bernard. 1998. Des infortune de la vertue scientifique. „Le monde”, 28 aout; http://www.homme-moderne.org/societe/socio/blahire/infortun. html; dostęp: 06.2010.

/// Lamont, Michele. 2009. How Professors Tbink. Inside the Curious World of Academic Judgment. Cambridge MA: Harvard University Press.

/// Latour, Bruno, Woolgar, Steve. 1986. Laboratory Life: The Construction of Scientific Facts (2 ${ }^{\text {nd }}$ edition). Ewing, NJ: Princeton University Press.

/// Levy, Bernard Henri. 2010. Wywiad dla pisma „Marianne”; http:/ / www. bernard-henri-levy.com/lintegralite-de-lentretien-choc-bhl-marianne-4033. html; dostęp: 04.2010.

/// Masson, Philippe. 2008. Faire de la sociologie. Les grandes enquêtes françaises depuis 1945. Paris: La Decouverte, col. Grands Repères.

/// Mauss, Marcel. 1969. OEuvres. T. 3. Paris: Ed. de Minuit.

/// Merton, Robert. 1968. The Matthew Effect in Science, Cumulative Advantage and the Symbolism of Intellectual Property. „Science”, January 5, nr 159(3810), s. $56-63$.

/// Merton, Robert. 1973. The Sociology of Science. Theoretical and Empirical Investigation. Chicago: The University of Chicago Press.

/// Merton, Robert. 1988. The Matthew Effect in Science, II Cumulative Advantage and the Symbolism of Intellectual Property. „ISIS”, vol. 79, s. 606-623.

/// Passeron, Jean-Claude. 2003. Mort d'un ami, disparition d'un penseur. W: Travailler avec Bourdieu. Paris: Flammarion, s. 17-90. 
/// Passeron, Jean-Claude. 2005. Que reste-t-il des Héritiers et de la Reproduction (1964-1971) aujourd'bui? Questions, méthodes, concepts et réception d'une sociologie de l'éducation. W: Chapoulie, Jean-Michel, Kourchid, Olivier, Robert, JeanLouis, Sohn, Anne-Marie (ed.). Sociologues et Sociologies. La France des années 60. Paris: L'Harmattan, 2005, s. 35-64, Logiques Sociales.

/// Pontille, David. 2004. La signature scientifique. Une sociologie pragmatique de l'attribution. Paris: CNRS editions.

/// Prost, Antoine. 2005. Les Héritiers et le contexte privilégié des années 19641968. W: Chapoulie, Jean-Michel, Kourchid, Olivier, Robert, Jean-Louis, Sohn, Anne-Marie (ed.). Sociologues et Sociologies. La France des années 60. Paris: L'Harmattan, 2005, s. 111-116, Logiques Sociales.

/// Putnam, Robert. 2000. Bowling Alone: The Collapse and Revival of American Community. New York: Simon \& Schuster.

/// Rabinov, Paul. 1996. Making PCR. A Story of Biotechnology. Chicago: The University of Chicago Press.

/// Reif, Fred, Strauss, Anselm. 1965. The Impact of Rapid Discovery upon the Scientist's Career. „Social Problem” 12.

/// Saint-Martin, Monique, de. 2003. Une infléxible domination? W: Travailler avec Bourdieu. Paris: Flammarion, s. 323-331.

/// Sayad, Abdelmalek. 1999. La double absence. Des illusions de l'émigré aux souffrances de l'immigré. Paris: Seuil, col. „Liber”.

/// Shapin, Steven. 2008. The Scientific Life: A Moral History of a Late Modern Vocation, Chicago: The University of Chicago Press.

/// Singly, François, de. 1998. Bourdieu: nom propre d'une entreprise collective. „Magazine littéraire”, octobre nr 369, s. 39-44; http://www.hommemoderne.org/societe/socio/dsingly/Bml9810.html; dostęp: 04.2010.

/// Sohn, Anne-Marie. 2005. Les ,jeunes”, la ,jeunesse” et les sciences sociales (1950-1970). W: Chapoulie, Jean-Michel, Kourchid, Olivier, Robert, JeanLouis, Sohn, Anne-Marie (ed.). Sociologues et Sociologies. La France des années 60. Paris: L'Harmattan, 2005, Logiques Sociales, s. 123-134.

/// Temime, Emile. 1999. Comprendre l'immigration - Quelques notes en mémoire d'Abdelmalek Sayad, un sociologue hors du commun. „Revue des Mondes Musulmans et de la Méditerranée", nr 85-86, s. 265-273.

/// Verdès-Leroux, Jeannine. 1998. Le Savant et la politique. Essai sur le terrorisme sociologique de Pierre Bourdieu. Paris: Éditions Grasset.

/// Verdrager, Pierre. 2010. Ce que les savants pensent de nous et pourquoi ils ont tort. Critique de Pierre Bourdieu. Paris: La Decouverte, Les empecheurs de penser en rond. 
/// Villette, Jean-Michel. 2002. Portait de Pierre Bourdieu en capitaliste sawvage. (wyd. pol.: Pierre Bourdieu jako kapitalista. Tłum. Zofia Boni. „Stan Rzeczy” 2010, nr 2).

/// Villette, Jean-Michel, Vuillermot, Catherine. 2009. From Predator to Icons, Exposing the Myth of Business Heros. Ithaca-New York: Cornell University Press.

/// Wagner, Izabela. 2005. Sprz̨żenie Karier. Konstrukcja karier w środowiskach artystycznych $i$ intelektualnych. „Przegląd Socjologii Jakościowej”, t. 1, nr 1; http:/ / www.qualitativesociologyreview.org/PL/archive_pl.php; dostęp: $03.2010 \mathrm{r}$.

/// Wagner, Izabela. 2006. La production sociale de virtuoses. Thèse de doctorat EHESS.

/// Wagner, Izabela. 2009. Coupling career fairy tale Fascinating Sociology Class'. How to teach sociology? The sociology of sociology. „Qualitative Sociology Review”, vol. V, Issue III. http://www.qualitativesociologyreview.org/ENG/ archive_eng.php; dostęp: 04.2010.

/// Wagner, Izabela. 2011. Mobilność $i$ kariery polskich elit naukonych: Becoming Transnational Professional. Warszawa: Wydawnictwo Naukowe Scholar.

/// Wagner, Izabela. 2010 Konstruowanie „międzynarodowej” tożsamości badacza nauk biologicznych. W: Anna Kacperczyk, Krzysztof Konecki (red.). Procesy to:ssamościowe. Symboliczno-interak.cyjny uymiar konstruowania ladu $i$ nieładu społeçnego. Lódź: Wydawnictwo Uniwersytetu Lódzkiego.

/// Yacine, Tassadit. 2003. L'Algérie, matrice d'une oeuvre. W: Travailler avec Bourdieu. Paris: Flammarion, s. 333-345.

/// Ziman, John. 1987. Knowing Everything about Notbing. Specialisation and Change in Scientific Careers. Cambridge: Cambridge University Press.

/// Znaniecki, Florian. 1984. Spoteczne role uczonych. Warszawa: Państwowe Wydawnictwo Naukowe.

/// Zuckerman, Harriet. 1977. Scientific elite: Nobel Laureates in the United States. New York: Free Press.

/// Żylicz, Maciej. 2006. Sukces i niepowodzenie w nauce. „Nauka”. Warszawa: Biuro Analiz Informacji Naukowej i Wydawnictw, s. 43-53.

\section{/// Abstrakt}

Artykuł porusza wybrane zagadnienia dotyczace karier naukowców. Odpowiadając na pytanie, czym jest sukces w nauce, a raczej: jak odnieść sukces, pracując w nauce, autorka analizuje kwestię współpracy naukowej, podziału 
pracy w zespołach badawczych, publikacji i ko-publikacji, a także ustalania autorstwa dzieł, będących rezultatem wspólnych badań. Biorąc pod uwagę dynamikę środowisk naukowych i pewne zmiany, które zachodzą w pracy przedstawicieli tego środowiska, podejmuje dyskusję na temat pewnych praktyk, które, mimo iż są rozpowszechnione, nie stanowią obiektu regulacji środowiskowych czy też szerszych rozważań w gronach skupiających przedstawicieli nauk humanistycznych i społecznych. Dzięki odmiennej perspektywie użytej $\mathrm{w}$ analizie karier naukowych niniejszy artykuł może zmodyfikować postrzeganie funkcjonowania naszego środowiska, a także być punktem wyjścia do szerszej dyskusji dotyczącej naszych codziennych praktyk.

Słowa kluczowe:

socjologia pracy, kariery naukowe, kariery twórcze, współpraca w nauce, sprzężenie karier

\section{///Abstract:}

\section{Genius or Businessman?}

\section{Career Coupling as a Way of Achieving Success in Science}

The article discusses selected elements of the scientists' ${ }^{6}$ careers. Addressing the question what constitutes success in science, I analyse scientific collaborations by focusing on the division of work among a research team, publication and co-publication process, and especially the acknowledgement of authorship in the case of publications based on research done by a team. Taking into account the dynamics of scientific milieus, I discuss some practices, which - despite being largely spread - hardly ever are the object of large and open discussions among the members of the world of human and social sciences. I hope that thanks to the perspective of sociology of work applied to the analysis of scientific careers, this paper will somewhat change the perception of functioning of our professional milieu and will be the starting point for a larger discussion about our daily practices.

Keywords:

sociology of occupation, career of scientists, creative careers, collaboration in science, career coupling 